\title{
Regulation of MLL/COMPASS stability through its proteolytic cleavage by taspase 1 as a possible approach for clinical therapy of leukemia
}

\author{
Zibo Zhao, ${ }^{1,2}$ Lu Wang, ${ }^{1,2}$ Andrew G. Volk, ${ }^{1,2,3,4}$ Noah W. Birch, ${ }^{1,2}$ Kristen L. Stoltz, ${ }^{1,2,5}$ \\ Elizabeth T. Bartom, ${ }^{1}$ Stacy A. Marshall, ${ }^{1,2}$ Emily J. Rendleman, ${ }^{1,2}$ Carson M. Nestler, ${ }^{1,2}$ \\ Joseph Shilati, ${ }^{1,2}$ Gary E. Schiltz, ${ }^{4,5,6}$ John D. Crispino, ${ }^{1,2,3,4}$ and Ali Shilatifard ${ }^{1,2,4}$ \\ ${ }^{1}$ Department of Biochemistry and Molecular Genetics, ${ }^{2}$ Simpson Querrey Center for Epigenetics, ${ }^{3}$ Division of Hematology/ \\ Oncology, ${ }^{4}$ Robert H. Lurie Comprehensive Cancer Center, Northwestern University Feinberg School of Medicine, Chicago, \\ Illinois 60611, USA; ${ }^{5}$ Center for Molecular Innovation and Drug Discovery, Northwestern University, Evanston, Illinois 60208, \\ USA; ${ }^{6}$ Department of Pharmacology, Northwestern University Feinberg School of Medicine, Chicago, Illinois 60611, USA
}

Chromosomal translocations of the Mixed-lineage leukemia 1 (MLL1) gene generate MLL chimeras that drive the pathogenesis of acute myeloid and lymphoid leukemia. The untranslocated MLL1 is a substrate for proteolytic cleavage by the endopeptidase threonine aspartase 1 (taspase1); however, the biological significance of MLL1 cleavage by this endopeptidase remains unclear. Here, we demonstrate that taspase1-dependent cleavage of MLL1 results in the destabilization of MLL. Upon loss of taspase1, MLL1 association with chromatin is markedly increased due to the stabilization of its unprocessed version, and this stabilization of the uncleaved MLL1 can result in the displacement of MLL chimeras from chromatin in leukemic cells. Casein kinase II (CKII) phosphorylates MLL1 proximal to the taspase1 cleavage site, facilitating its cleavage, and pharmacological inhibition of CKII blocks taspase1-dependent MLL1 processing, increases MLL1 stability, and results in the displacement of the MLL chimeras from chromatin. Accordingly, inhibition of CKII in a MLL-AF9 mouse model of leukemia delayed leukemic progression in vivo. This study provides insights into the direct regulation of the stability of MLL1 through its cleavage by taspase1, which can be harnessed for targeted therapeutic approaches for the treatment of aggressive leukemia as the result of MLL translocations.

[Keywords: taspase1; TASP1; MLL1; KMT2A; protein stability; CKII; CX-4945; regulation of gene expression] Supplemental material is available for this article.

Received August 13, 2018; revised version accepted November 2, 2018.

Threonine aspartase 1 (taspase1) is a unique endopeptidase that cleaves its protein substrates using threonine as the active nucleophile. Taspase1 was originally identified as the protease for mixed-lineage leukemia 1 (MLL1), and, later on, only limited numbers of taspase 1 substrates were identified, which included MLL1, MLL2, and TFIIA in mammalian cells (Hsieh et al. 2003a; Takeda et al. 2006; Zhou et al. 2006) and HCF1 in Drosophila (dHCF1) (Capotosti et al. 2007). The proteolytic cleavage of TFIIA has been well documented: The uncleaved TFIIA is involved in active transcription in the nucleus, whereas the cleaved TFIIA by taspase 1 is less stable and targeted for proteasome-mediated degradation (Høiby et al. 2004; Zhou et al. 2006). Although dHCF1 undergoes proteolytic maturation by Drosophila taspase1 (Capotosti et al. 2007),

Corresponding author: ash@northwestern.edu Article published online ahead of print. Article and publication date are online at http://www.genesdev.org/cgi/doi/10.1101/gad.319830.118. mammalian HCF1 is cleaved by $\mathrm{N}$-acetylglucosamine (O-GlcNAc) transferase (OGT), which displays the species-specific divergence in this maturation process (Capotosti et al. 2011; Daou et al. 2011; Wunsch et al. 2015). In contrast to TFIIA and HCF1, the biological significance of MLL1 cleavage by taspase 1 remains unclear and controversial (Hsieh et al. 2003a; Takeda et al. 2006; Yokoyama et al. 2013).

MLL1 is one of the members of the histone H3 Lys4 (H3K4) methyltranferases found within the COMPASS (complex of proteins associated with Set1) family (Miller et al. 2001; Schuettengruber et al. 2017) that implements $\mathrm{H} 3 \mathrm{~K} 4$ trimethylation $(\mathrm{H} 3 \mathrm{~K} 4 \mathrm{me} 3)$ on a subset of

(C) 2019 Zhao et al. This article is distributed exclusively by Cold Spring Harbor Laboratory Press for the first six months after the full-issue publication date (see http://genesdev.cshlp.org/site/misc/terms.xhtml). After six months, it is available under a Creative Commons License (Attribution-NonCommercial 4.0 International), as described at http://creativecommons.org/licenses/by-nc/4.0/. 
transcriptionally active genes in mouse embryonic fibroblasts (MEFs) and H3K4 dimethylation (H3K4me2) predominantly at $\mathrm{CpG}$-dense regions to regulate target gene expression (Wang et al. 2009; Rickels et al. 2016). Taspase 1 proteolytically processes the full-length MLL1 protein into a $320-\mathrm{kDa}$-terminal fragment (MLL1N) and a 180-kDa C-terminal fragment (MLL1C) at two conserved cleavage sites (D/GADD and D/GVDD motifs), and the two fragments further associate to form a stable dimer (Yokoyama et al. 2002; Hsieh et al. 2003a,b). The N-terminal half of MLL1 contains AT hook domains (ZeleznikLe et al. 1994), a CXXC domain, PHD domains, and a bromodomain, which may function for chromatin binding (Fair et al. 2001). The C-terminal half of MLL1 contains a transactivation domain and a SET domain with histone H3K4 methyltransferase activity (Milne et al. 2002; Nakamura et al. 2002).

The MLL1 gene is found in chromosomal translocations with a large number of partner genes in childhood leukemia. In most cases, the leukemogenic fusion proteins contain the N-terminal half of MLL1 fused in-frame to the C-terminal translocation partners, resulting in the absence of the taspase 1 cleavage sites from these chimeric proteins. The stability of the MLL chimeras exceeds the wild-type copy of MLL1 in leukemic cells, and these chimeras drive the oncogenic target gene expression, including HOXA4, HOXA5, HOXA9, and MEIS1 (Armstrong et al. 2002; Ayton and Cleary 2003; Wong et al. 2007; Wang et al. 2012a; Liang et al. 2017).

Different mouse models of leukemia have been established to study the biological consequences of MLL1 cleavage by taspase1 (Takeda et al. 2006; Yokoyama et al. 2013; Dong et al. 2014); however, no consistent conclusions have been reached. In one study, taspase $1^{-/-}$mice and knock-in mice with homozygous noncleavable alleles of MLL1 and/or MLL2 were generated (Takeda et al. 2006). Taspase1-deficient cells exhibited deregulated cell cycle genes, and MEFs bearing the noncleavable (nc) alleles of MLL1 also showed proliferation defects, suggesting that MLL1 is the crucial substrates for taspase1-coordinated cell proliferation (Takeda et al. 2006). In another study, knock-in mice bearing homozygous noncleavable alleles of MLL1 displayed no apparent defects, and MLL1 ${ }^{\text {nc/nc }}$ MEFs bearing these mutations demonstrated normal proliferation and no changes in MLL1 target gene expression (Yokoyama et al. 2013). The discrepancies could arise from differences in the mouse models and the distinct downstream events examined in each case (cell cycle genes and MLL1 target genes, respectively).

To address these inconsistencies, we used CRISPR/ Cas9 gene editing to knock out the TASP1 gene in human cancer cell lines. Our study demonstrates that instead of activation and maturation of MLL1, taspase1-dependent cleavage of MLL1 leads to higher rates of its turnover. We further demonstrated that phosphorylation of MLL1 by casein kinase II (CKII) facilitates the cleavage by taspase1, and pharmacological inhibition of CKII blocks MLL1 cleavage, increases MLL1 stability, and displaces the MLL chimeras from chromatin. Pharmacological inhibition of CKII substantially delayed leukemic progression in the MLL-AF9 mouse model of leukemia. Our study provides a possible targeted therapeutic approach for MLLrearranged leukemia through the regulation of MLL1 stability by inhibition of its cleavage by taspase 1 .

\section{Results}

Loss of taspase 1 results in MLL1 processing and localization

In order to systematically investigate the functions of taspase 1 in mammalian cells and the potential therapeutic value of this process in human cancers, we used CRISPR/Cas9 technology to knock out taspase1 in several different cell lines, including 293T (Fig. 1A), MCF7 breast cancer, and HCT116 colorectal cancer cells (Supplemental Fig. S1A,B). For 293 T cells, we generated two independent clones of homozygous taspase1 knockout cells (C49 and C104). Loss of taspase1 in both C49 and C104 knockout clones resulted in defects in cleavage of MLL1, MLL2, and TFIIA, the known nuclear substrates of taspase 1 (Hsieh et al. 2003a; Takeda et al. 2006; Zhou et al. 2006), whereas substrate cleavage was not affected in the heterozygous clone C45 (Fig. 1B; Supplemental Fig. S1A,B). The global histone H3K4 methylation levels (H3K4me1/2/3), as measured by Western analysis, remained the same in taspase1 homozygous knockout clones compared with wild-type cells (Fig. 1C; Supplemental Fig. S1C).

Previous studies reported that the proteolytic cleavage of MLL1 by taspase1 activated MLL1 and enabled the translocation of MLL1 from the cytoplasm to the nucleus for proper activation of gene expression (Hsieh et al. 2003a; Zhang et al. 2013; Wang et al. 2016). In our study, when taspase 1 wild-type and knockout $293 \mathrm{~T}$ cell lysates were fractionated, both MLL1 and MLL2 were found solely in the nuclear fractions in both taspasel wild-type and knockout cells (Fig. 1D). Similar results were obtained with immunofluorescence where MLL1 and MLL2 staining overlapped with DAPI-stained nuclei in both taspase1 wild-type and knockout cells, demonstrating that the cellular localization of MLL1 and MLL2 is not altered by the loss of taspase1 (Fig. 1E; Supplemental Fig. S1D,E). Furthermore, MLL/COMPASS subunits, including Menin, LEDGF, ASH2L, and RbBP5, interacted with both cleaved and noncleaved MLL1 (Supplemental Fig. S1F), and cleaved and uncleaved MLL1 exhibited the same elution profile on size exclusion chromatography (Supplemental Fig. S1G), indicating that MLL/COMPASS general assembly is not significantly altered in the taspase 1 knockout cells.

\section{Taspase1-dependent cleavage of MLL1 regulates its stability}

Taspase1 has been shown to cleave TFIIA and target it for proteasomal degradation in the cytoplasm (Zhou et al. 2006). We found that MLL1 protein stability also has a relatively fast turnover, as seen by the kinetics of its degradation in the presence of cycloheximide (CHX) (Supplemental Fig. S2). We therefore investigated whether 
A

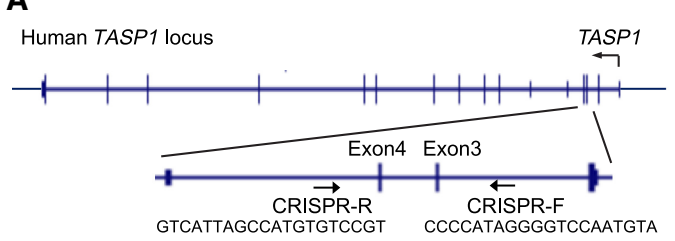

B

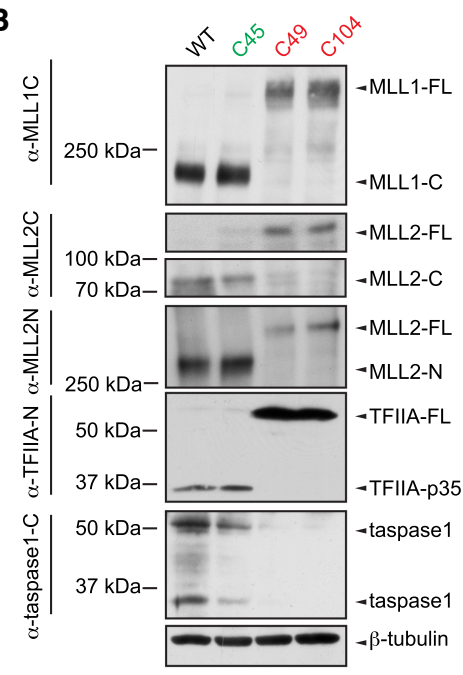

C

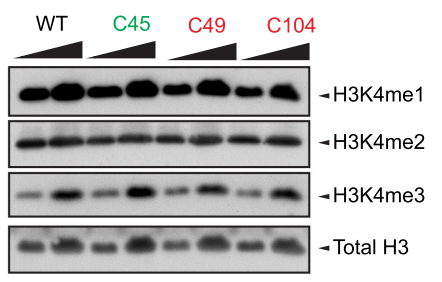

D
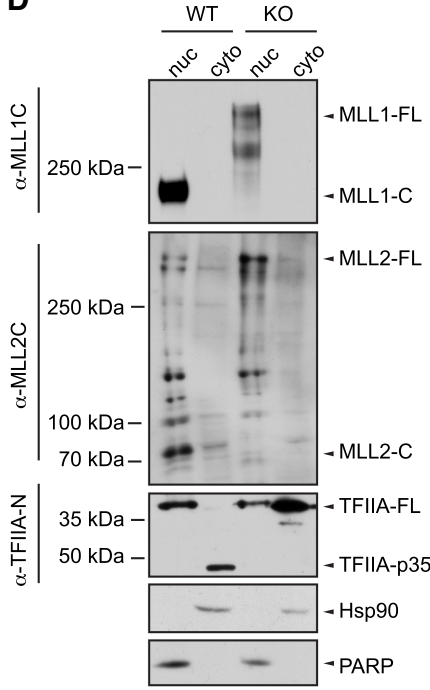

E

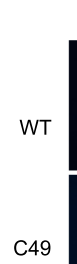

C104

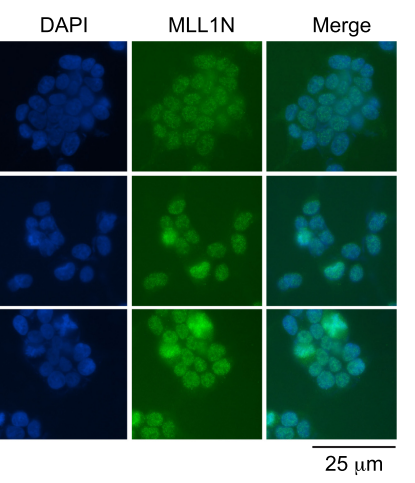

Figure 1. Loss of taspasel affects MLL processing but not subcellular localization. (A) Generation of taspase1 knockout 293T cells by CRISPR/Cas9 targeted genomeediting technology. (B) Western blot showing the protein levels and apparent molecular weights of MLL1, MLL2, TFIIA, and taspase1, which are known substrates of taspasel. C45 is a heterozygous clone, and C49 and C104 are knockout clones for the TASP1 gene. (C) Bulk histone H3K4me1, H3K4me2, and $\mathrm{H} 3 \mathrm{~K} 4 \mathrm{me} 3$ levels are unchanged. Totallevels of histone H3K4me1, H3K4me2, and $\mathrm{H} 3 \mathrm{~K} 4 \mathrm{me} 3$ were examined with histone $\mathrm{H} 3$ as the internal control. $(D)$ Cellular fractionation showing that both cleaved and noncleaved MLL1 and MLL2 were localized in the nuclear fraction. Full-length TFIIA was preferentially accumulated in the cytoplasmic fraction in taspase1 knockout cells. Hsp90 and PARP were used as cytoplasmic and nuclear fraction biomarkers, respectively. (E) Immunofluorescence showing the nuclear localization of MLL1 protein in both wild-type and taspase 1 knockout 293T cells. Anti-MLL1N, DAPI staining, and merge are shown. taspase1 regulates MLL1 protein stability using the taspase1 wild-type and knockout cells. First, we demonstrated that the mRNA transcripts for both KMT2A (MLL1) and $K M T 2 B$ (MLL2) genes remained constant in taspase 1 wild-type and knockout cells (Fig. 2A), demonstrating that taspase 1 does not control the transcription of these genes. We then performed CHX pulse-chase experiments to measure the MLL1 protein degradation rate in various taspasel wild-type and knockout cells (Fig. 2B-G). Upon $8 \mathrm{~h}$ of CHX treatment, MLL1 in wild-type cells was degraded, while the uncleaved MLL1 in the taspase1 knockout cells was more resistant to degradation (Fig. 2C). MLL2 and TFIIA proteins were not degraded during this period of CHX treatment in both wild-type and taspase1 knockout cells (Fig. 2C). The increased stability of MLL1 in the absence of taspase1 was also observed with increasing concentrations of $\mathrm{CHX}$ treatment in the MCF7 and HCT116 taspase1 knockout cells (Fig. 2D-G). Moreover, we confirmed that the degradation of MLL1 is proteasomal-dependent, as MG132 treatment partially rescued the degradation of MLL1 induced by CHX in both taspase1 wild-type and knockout cells (Fig. 2H). Collectively, our results suggest that the proteolytic cleavage of MLL1 by taspase1 primes the MLL1 protein for degrada- tion (Fig. 2) without altering the cellular localization of MLL1 (Fig. 1D,E).

\section{Increased chromatin occupancy of MLL1 in taspase1 knockout cells}

To differentiate the functional outcome and localization patterns of the cleaved MLL1 and its uncleaved version in taspase 1 knockout cells, we performed chromatin immunoprecipitation (ChIP) followed by next-generation sequencing (ChIP-seq) using MLL1 N-terminal and Cterminal antibodies as well as an MLL2 C-terminal antibody (Fig. 3; Supplemental Fig. S3). We first confirmed the specificity of the our MLL1N and MLL1C antibodies in ChIP-seq by knocking down MLL1 in 293T cells (Supplemental Fig. S3A). A genome browser view of the complete chromosome 1 shows that the majority of MLL1 peaks are lost as the result of MLL1 knockout (Supplemental Fig. S3B). To quantitatively measure the binding of MLL1 on the chromatin in taspasel wild-type and knockout cells, the occupancy of the cleaved and uncleaved MLL1 were compared (Fig. 3). Both MLL1C and MLL1N signal intensities were increased in taspasel knockout cells $\left(P\right.$-value $\left.<2.2 \times 10^{-16}\right) \quad$ (Fig. $\left.3 \mathrm{~A}-\mathrm{F}\right)$, while MLL2 


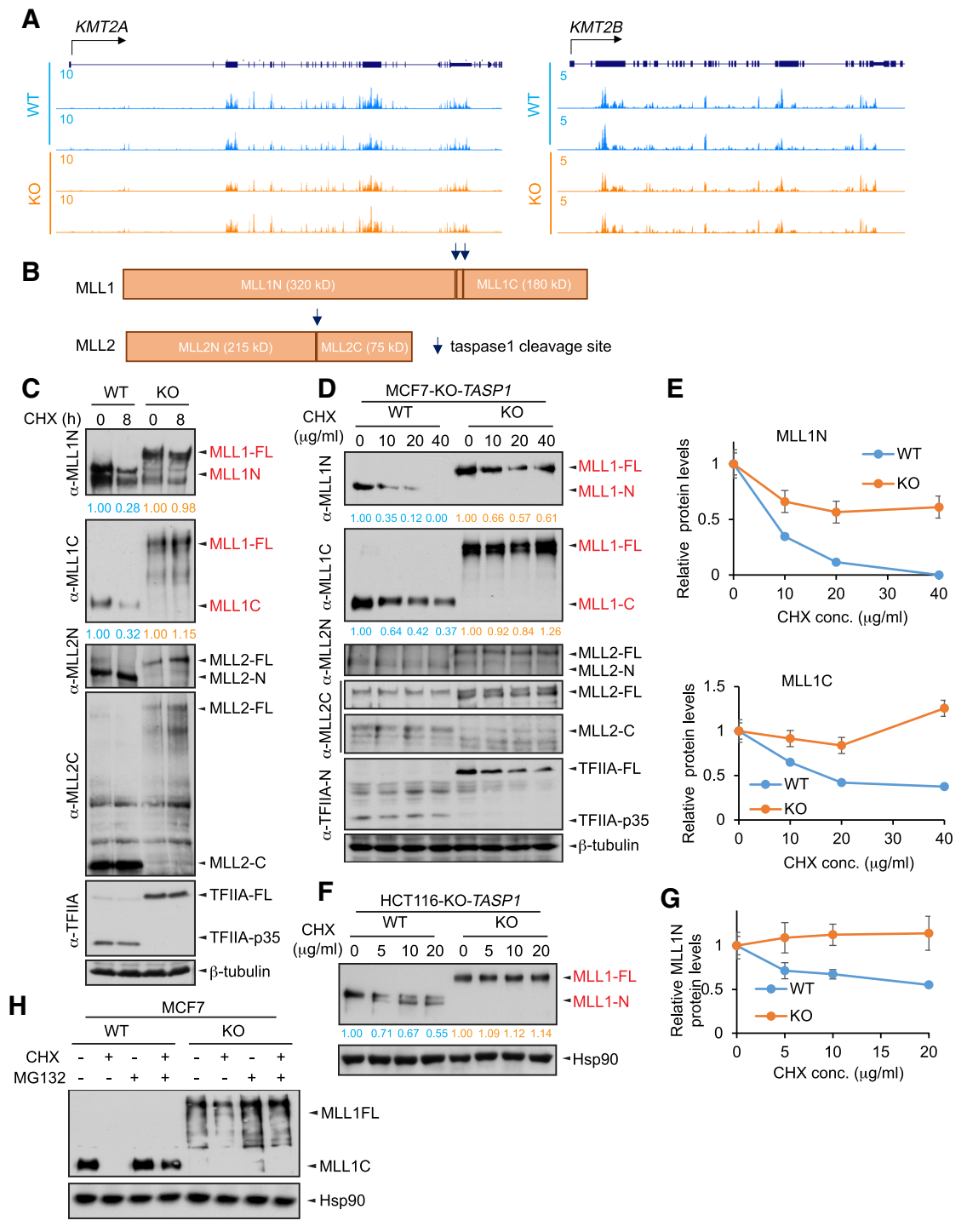

Figure 2. Taspase1-dependent cleavage of MLL1 regulates its stability. (A) KMT2A (MLL1) and KMT2B (MLL2) mRNA levels are not affected by tasapsel knockout, as shown by RNA sequencing (RNA-seq). $(B)$ Schematic diagram showing the taspase 1 cleavage sites in MLL1 and MLL2. (C) 293 T taspasel wild-type and knockout cells were treated with $50 \mu \mathrm{g} / \mathrm{mL}$ CHX for 0 or 8 h. Cell lysates were collected and immunoblotted with MLL1, MLL2, and TFIIA. $(D, E)$ MCF7 taspase1 wild-type and knockout cells were treated with different concentrations of $\mathrm{CHX}(0,10,20$, or $40 \mu \mathrm{g} /$ $\mathrm{mL}$ ) for $8 \mathrm{~h}$. Cell lysates were collected and immunoblotted for MLL1, MLL2, and TFIIA. $(F, G)$ HCT116 taspase1 wild-type and knockout cells were treated with 0,5 , 10 , or $20 \mu \mathrm{g} / \mathrm{mL}$ CHX for $8 \mathrm{~h}$. Cell lysates were collected and immunoblotted with MLL1. (H) MCF7 taspase1 wild-type and knockout cells were pretreated with $1 \mu \mathrm{M}$ MG132 for $2 \mathrm{~h}$ followed by another $8 \mathrm{~h}$ of $20 \mu \mathrm{g} / \mathrm{mL}$ CHX. Cell lysates were collected and immunoblotted for MLL1. Quantification of MLL1 protein levels was performed with ImageJ. chromatin occupancy was not altered in taspase1 knockout cells (Fig. 3G-I), suggesting that the loss of taspase1 leads to increased MLL1 stability and occupancy on chromatin. We also observed increased occupancy of MLL1 on chromatin in MCF7 taspase1 knockout cells (Fig. 3JO). Genome browser views of the ZMYND11, NEK1, CLCN3, and CASC5 loci demonstrate increased MLL1 occupancy in taspase 1 knockout cells (Fig. 3P-R). Together, these data suggest that there is less MLL1 protein turnover on chromatin in the absence of taspase 1.

\section{Stabilized MLL1 as the result of taspase1 loss can displace $M L L$ chimeras from chromatin}

To directly dissect the gene expression signature controlled by taspase 1 and by cleaved MLL1 and full-length MLL1 in taspasel wild-type and knockout cells, we performed RNA sequencing (RNA-seq) analyses in taspase1 wild type and knockout with MLL1 knockdown (Supplemental Fig. S4A). Knockdown of MLL1 in wild-type cells or in TASP1 knockout cells resulted in similar changes in gene expression, suggesting that the uncleaved MLL1 in taspase 1 knockout cells retained the same functionality in gene expression (Supplemental Fig. S4B,C). MLL1/ COMPASS has been demonstrated to function as a histone H3K4 methyltrasferase (Wang et al. 2009; Piunti and Shilatifard 2016; Rickels et al. 2016). Therefore, we wanted to determine the status of $\mathrm{H} 3 \mathrm{~K} 4$ methylation on chromatin in the cleaved and uncleaved MLL1 and determine whether the cleavage of MLL1 by taspase1 is associated with changes in the pattern of expression. Our study demonstrated that the pattern of histone H3K4 methylation on chromatin is not significantly altered at the regions where MLL1 binding was increased (Supplemental Fig. S4D,E).

MLL fusion proteins exert their oncogenic functions in leukemic cells through the recruitment of the superelongation complex (SEC) to induce rapid transcriptional release to drive leukemogenesis (Lin et al. 2010; Smith et al. 2011; Luo et al. 2012). We postulated that the increased association of wild-type MLL1 (uncleaved form) in the absence of tasapse1 might prevent or displace the recruitment of MLL chimeras. To address this hypothesis, taspase1 wild-type 

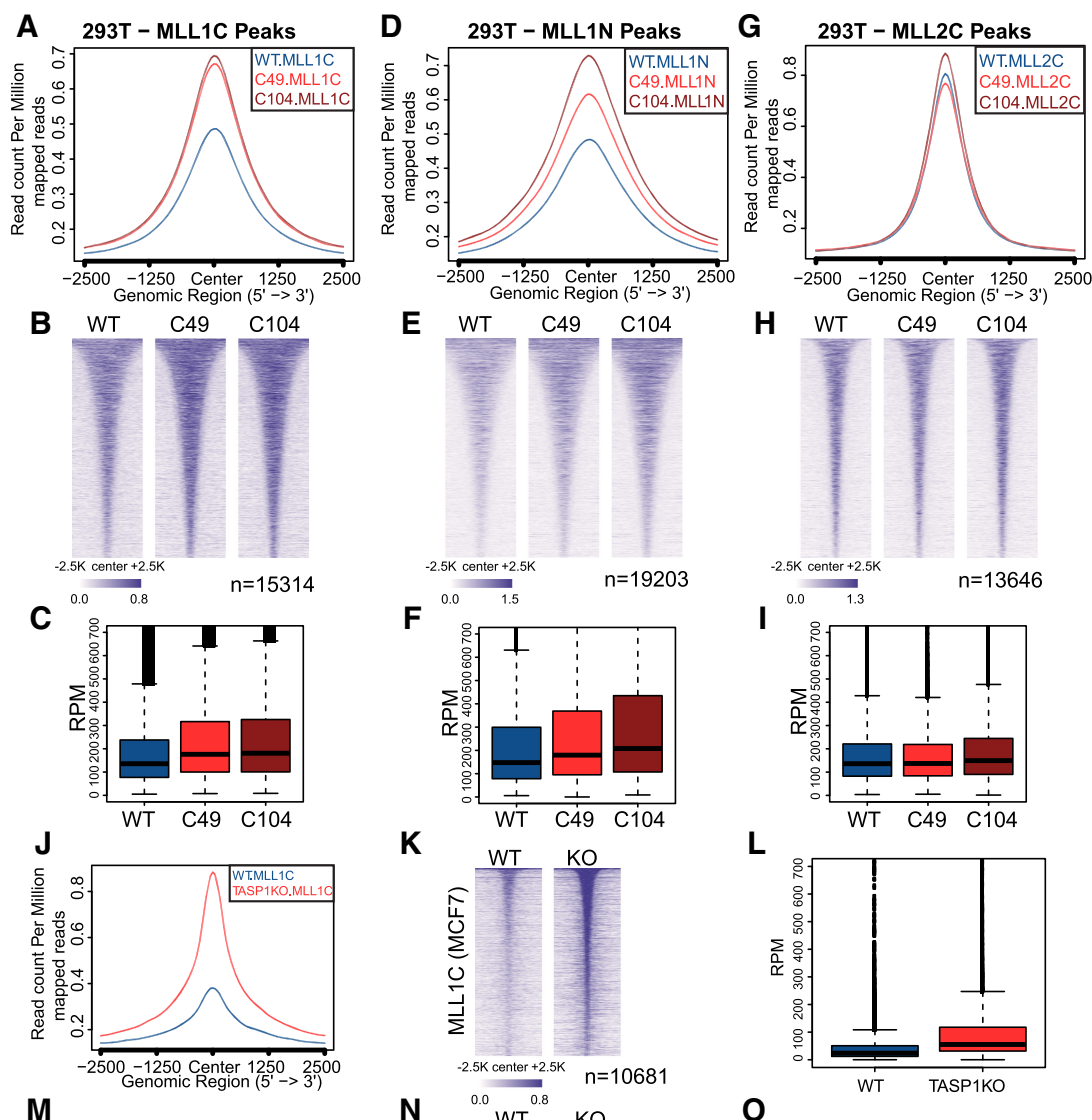

K
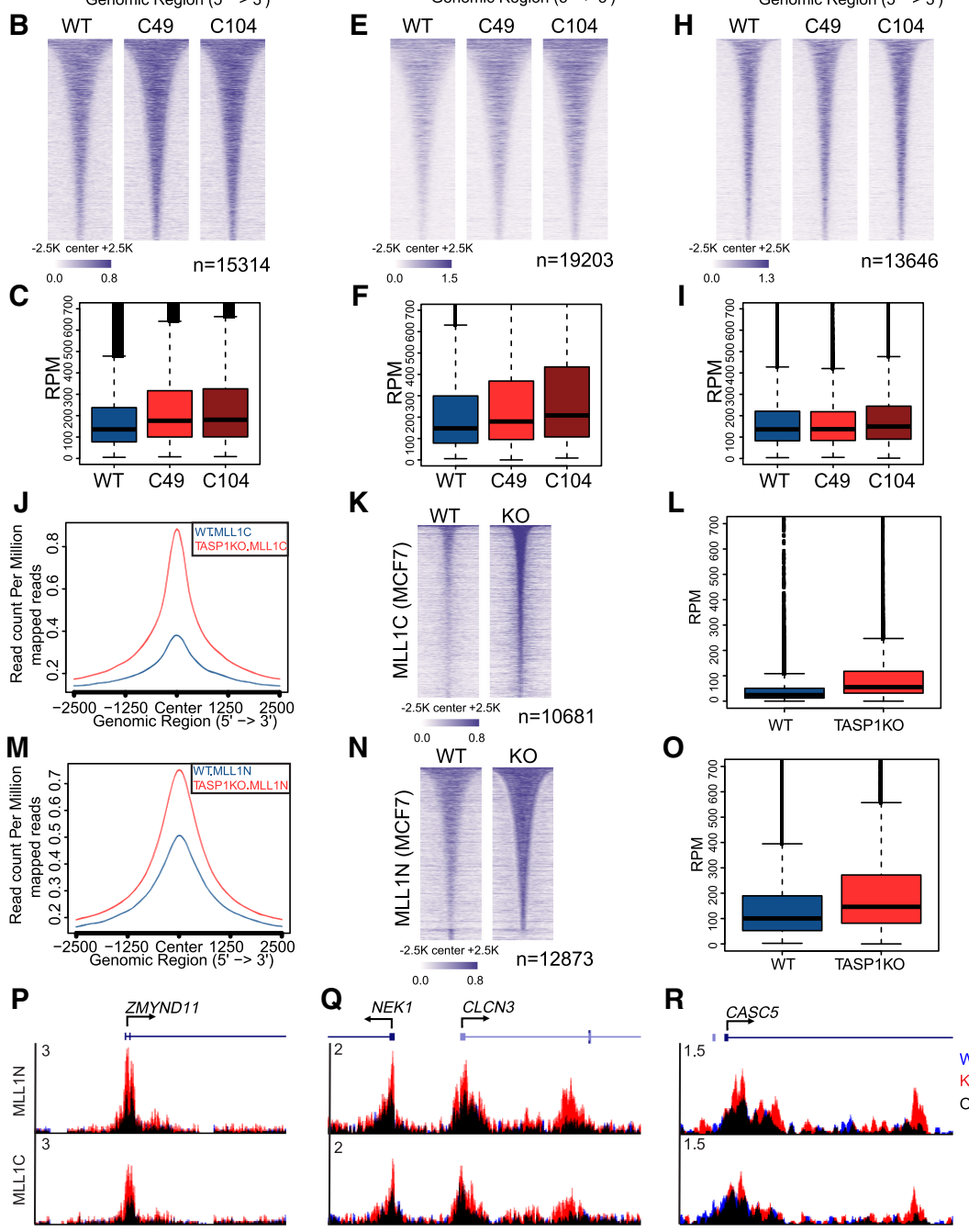

$\mathbf{N}$
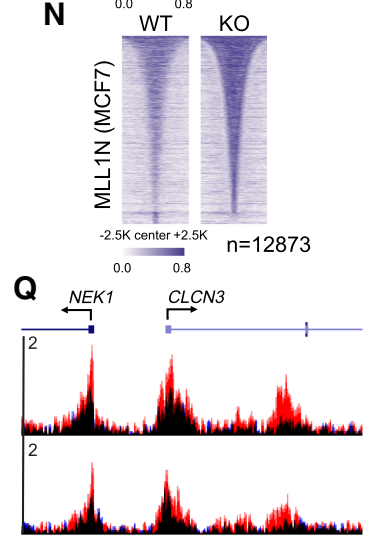

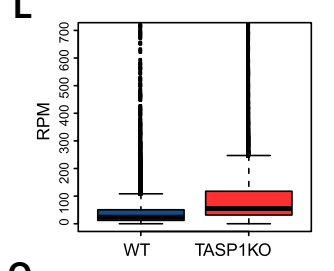

0

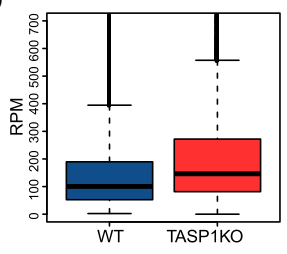

$\mathbf{R}$

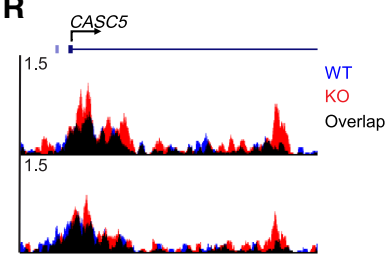

Figure 3. Increased occupancy of MLL1 with chromatin in taspasel knockout cells. $(A-O)$ Coverage profiles, heat maps, and box plots of MLL1C $(A-C)$, MLL1N $(D-F)$, and MLL2C $(G-I)$ in 293T cells and of MLL1C $(J-L)$ and MLL1N $(M-O)$ in MCF7 cells are shown. A region within $2.5 \mathrm{~kb}$ around the center of MLL1C, MLL1N, or MLL2C is displayed. For the heat maps, profiles are centered within $2.5 \mathrm{~kb}$ of MLL1- or MLL2-occupied peaks and sorted in descending order of MLL1C, MLL1N, or MLL2C occupancy in wild-type cells. Box plots show quantitation of the MLL1 occupancy in $293 \mathrm{~T}$ cells in replicates. $(P-R)$ Genome browser track examples of ZMYND11, NEK1, CLCN3, and CASC5 show the increased occupancy of noncleavable MLL1 in the taspase1 knockout 293T cells enriched in both the promoter region and the gene body. and knockout $293 \mathrm{~T}$ cells were transfected with equal amounts of MLL-AF4 fusion constructs (Fig. 4A). Elevennineteen lysine-rich leukemia protein 2 (ELL2) is a subunit of SEC (Shilatifard et al. 1997; Lin et al. 2010; Smith et al. 2011; Luo et al. 2012), and its occupancy in taspase1 wild-type and knockout cells was examined by ChIP-seq. We found that 867 genomic regions demonstrated a significant decrease in the binding of the ELL2 subunit of the SEC to chromatin in taspase1 knockout cells compared with that in the wild-type cells (Fig. 4B), and these regions exhibited elevated levels of uncleaved MLL1 proteins (Fig. 4C). Genome browser views of the promoter regions of the C6orf211, KBTBD4, NDUFS3, ELF2, and $P D E 7 A$ loci demonstrate that the exclusion of ELL2 in the presence of MLL-AF4 fusion proteins was due to the preferential binding of noncleavable MLL1 at the same region (Fig. 4D). Collectively, our data suggest that uncleaved MLL1 in the absence of tasapsel can displace MLL chimera occupancy, suggesting this pathway as a possible new therapeutic approach for the treatment of MLL1 translocation-based childhood leukemia.

\section{Inhibition of CKII selectively increases full-length MLL1 protein levels}

Given the importance of taspase1-dependent cleavage for the regulation of MLL1 stability, we envisioned two independent approaches to interfere with the MLL1 cleavage by taspase1: (1) pharmacological inhibition of tasapse1, resulting in the inactivation of taspase 1 and noncleavage of 
A
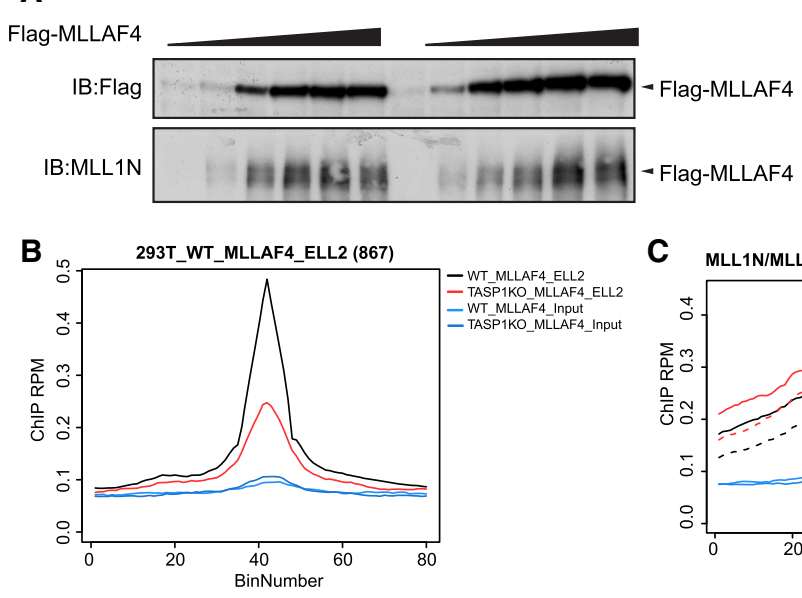

C MLL1N/MLL1C peaks centered on ELL2
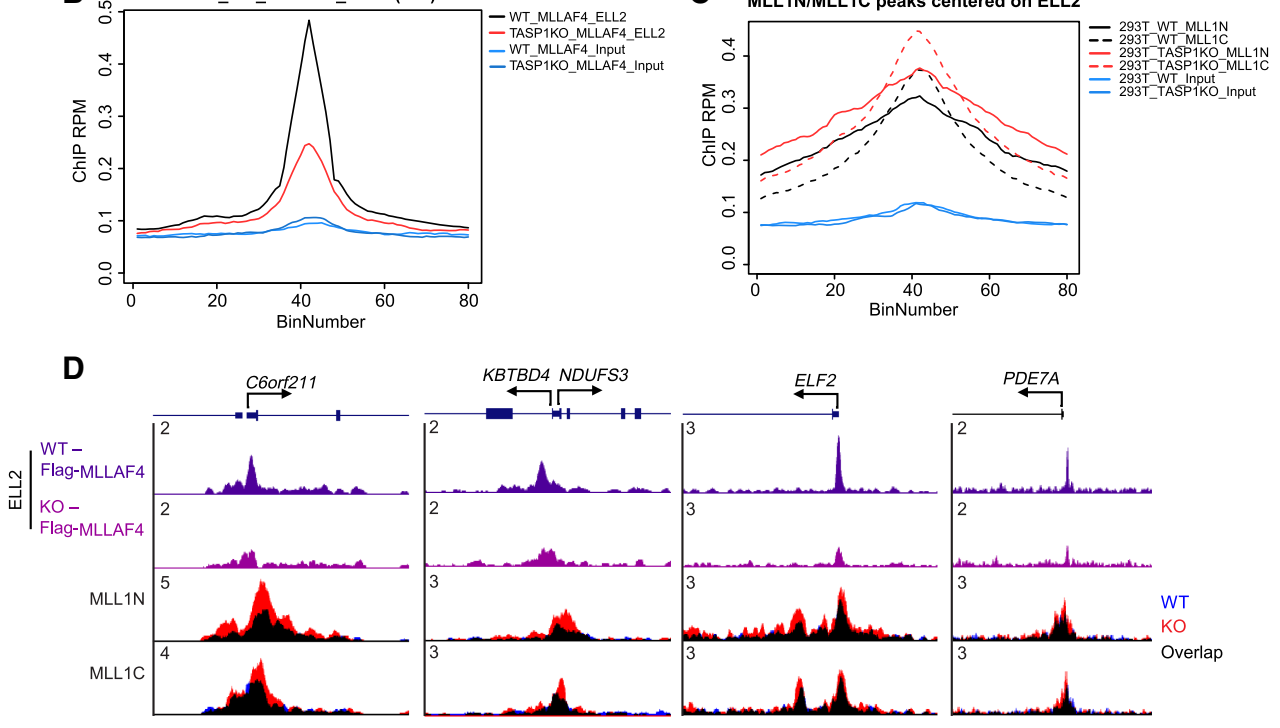

Figure 4. Stabilized MLL1 in taspase1-null cells can displace MLL chimeras from chromatin. $(A)$ Taspase1 wild-type and knockout cells were transfected with Flag-MLLAF4 plasmid for $30 \mathrm{~h}$. (B) ChIP-seq experiments were performed using an antibody against ELL2. Average plot showing the 867 binding regions of ELL2 with a significant decrease in taspase1 knockout cells compared with that in taspase1 wildtype 293T cells. (C) Average plot showing the MLL1 binding using MLL1N and MLL1C antibodies in taspase1 knockout and wild-type 293 T cells using the 867 regions identified in $B$. $(D)$ Genome browser track examples showing the decreased ELL2 recruitment and concomitant increase of MLL1 binding in tasapse1 knockout cells at MLL chimera target genes.

its substrates (MLL1, MLL2, TFIIA, etc.), and (2) modulation of the cleavage efficiency by targeting MLL1 itself without affecting the activity of taspase 1 and other substrates. Previous efforts in identifying specific taspase 1 inhibitors demonstrated limited success (Stauber et al. 2012; Wünsch et al. 2012, 2016). Our own virtual screen of $30,000,000$ compounds for taspase1 inhibitors using the crystal structure of taspasel (Khan et al. 2005) yielded 26 candidates, none of which was effective in blocking taspasel activity in vitro or in vivo (data not shown). Taspase1 could be a particularly difficult protease to target due to its unique structure and/or the extreme potency of this particular protease. We found that knocking down taspasel by $70 \%$ was not sufficient to affect cleavage of MLL1 and MLL2 (Supplemental Fig. S5A,B), suggesting that an extremely high degree of taspasel inhibition would be required to achieve changes in MLL1 cleavage and stability.

Our second approach focused on targeting the taspase 1 substrate: the MLL1 cleavage site. For this purpose, we generated several reporters, including 3xFlag-tagged MLL1-p75, MLL2-p69, and full-length TFIIA harboring their respective taspasel cleavage sites, and expressed them in taspase1 wild-type and knockout cells in order to test the cleavage efficiency (Supplemental Fig. S5C-F). Interestingly, we found several serine and threo- nine residues near the taspasel cleavage sites that were phosphorylated based on the PhosphoSitePlus database (Fig. 5A; Hornbeck et al. 2015). When the phosphorylation sites on the reporter constructs were mutated to alanine (AA), cleavage efficiency was dramatically diminished, while the phosphomimetic aspartate (DD) mutations were cleaved similarly to the wild-type MLL1 reporters (Fig. 5B, cleaved MLL is marked by a red arrow). Furthermore, when the wild-type or AA reporters were cotransfected with HA-tagged taspase1, the AA mutant reporter was more resistant to cleavage than the wild-type reporter (Fig. 5C). To predict which kinases may phosphorylate MLL1 on the serine and threonine near the cleavage sites, we used the NetPhosK 1.0 server, and the top predicted kinase was CKII based on the score of the prediction confidence and the similarity to one or more of the phosphorylation sites used in training the method (Supplemental Fig. S6A; Blom et al. 2004). The general consensus recognition motifs for phosphorylation by CKII are pSXXE/D, $\mathrm{pSXE} / \mathrm{D}, \mathrm{pSE} / \mathrm{D}, \mathrm{pS} / \mathrm{pTD} / \mathrm{EXD} / \mathrm{E}$, and variations of these sequences (Meggio et al. 1994; Sarno et al. 1996; Rush et al. 2005). T2724 and S2726 of MLL1 fall within the consensus sequence recognized by CKII (Fig. 5B). Therefore, we first knocked down the catalytic subunits of CKII and examined the MLL1 cleavage in 293T cells. We 
A

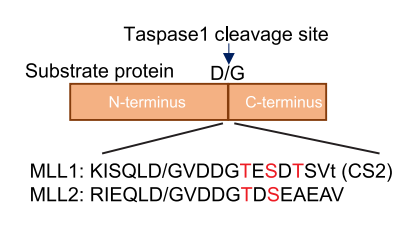

B

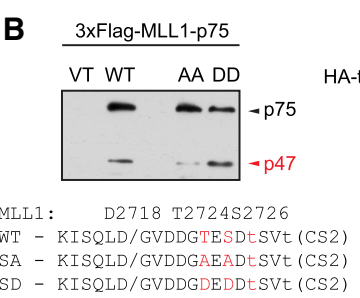

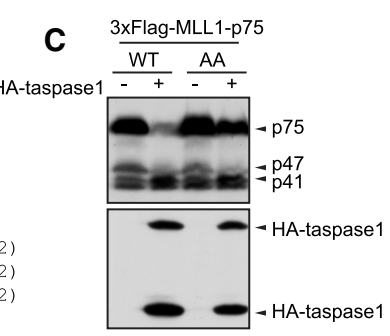

F

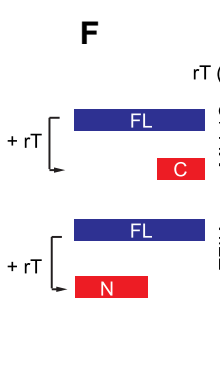

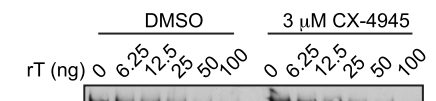

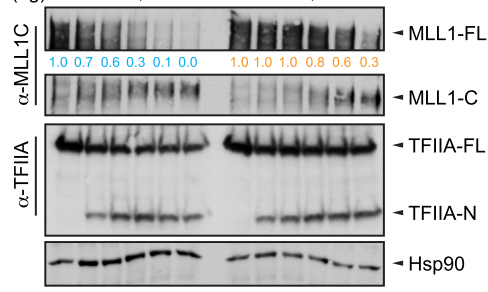

E

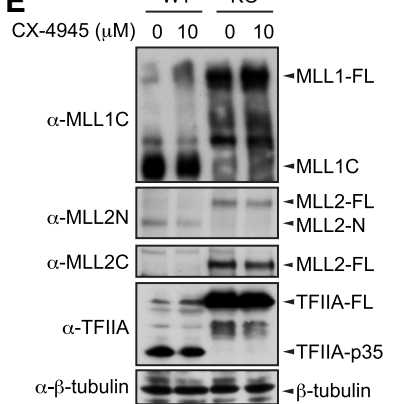

H

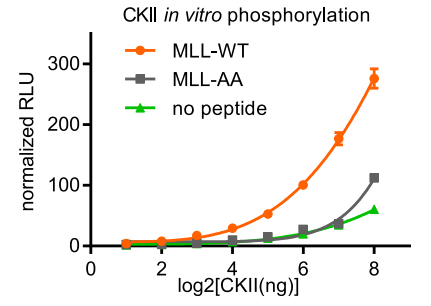

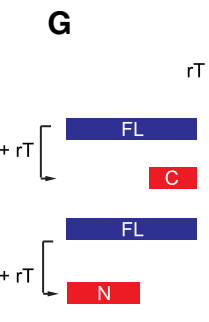

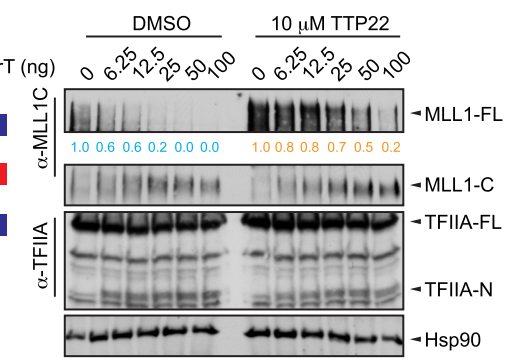

I

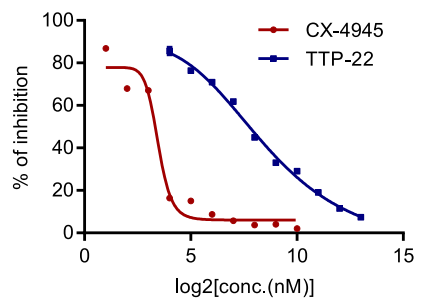

Figure 5. CKII inhibition selectively increases full-length MLL1 protein levels. (A) Conservation of the sequences flanking MLL1-CS2 and MLL2 cleavage sites, with phosphorylated serine and threonine residues highlighted in red. (B) $293 \mathrm{~T}$ cells were transfected with vector control (VT), wild-type, AA, or DD reporter constructs of MLL1-p75. Western blot was performed with anti-Flag antibody for MLL1 (p75: full length; p47: cleaved). (C) 293T cells were transfected with wild-type or AA reporter constructs of MLL1-p75 in the presence or absence of overexpressed HA-taspase1. Western blotting was performed with antiFlag antibody for MLL1 and anti-HA antibody for taspase $1 .(D) 293 \mathrm{~T}$ cells were infected with shRNAs against CKII $\alpha$ or CKII $\alpha^{\prime}$. Western blotting was performed with antiMLL1C antibody to assess MLL1 full-length protein levels. Two exposures are shown. CKIIa or CKII $a^{\prime}$ Western blots are shown to assess knockdown efficiencies. (E) 293T cells were treated with DMSO or $10 \mu \mathrm{M}$ CX-4945 for $30 \mathrm{~h}$. Cells were harvested and lysed for Western blotting against MLL1, MLL2, or TFIIA, with $\beta$-tubulin as the loading control. $(F, G) 293 \mathrm{~T}$ taspase1 knockout cells were pretreated with $3 \mu \mathrm{M}$ CX-4945 or $10 \mu \mathrm{M}$ TTP22 for $30 \mathrm{~h}$. Whole-cell lysates from the two conditions were incubated with increasing concentrations of His-taspase 1 and subjected to in vitro taspase 1 assay. $(H)$ CKII in vitro phosphorylation assay using the MLL wild-type (GVDD/ GTESDTSVTAT) or MLL-AA (GVDD/ GAEADTSVTAT) peptide. The MLL wildtype, but not the MLL-AA, peptide can be phosphorylated by CKII. (I) Dose-dependent inhibition of MLL wild-type peptide phosphorylation by CKII inhibitors CX-4945 and TTP-22. observed a consistent increase of MLL1 full-length protein levels with either CKII $\alpha$ or CKII $\alpha^{\prime}$ knockdown (Fig. 5D). Next, we tested four CKII inhibitors (namely, CX-4945, TTP22, DMAT, and TTB), which differ in their $\mathrm{IC}_{50}$ values (Supplemental Fig. S6B,C). Treatment of CX-4945 and TTP22 demonstrated a dose-dependent increase in MLL1 full-length protein levels in our cell-based assays (Supplemental Fig. S6D) and were selected for further validation. We also established an in vitro taspasel cleavage assay using taspase1 knockout cell lysates and His-tagged tasapse1 recombinant proteins (Supplemental Fig. S6E,F). CX-4945 treatment led to increased full-length MLL1 without affecting the cleavage of MLL2 or TFIIA in vivo (Fig. 5E). Finally, when taspase1 knockout cells were pretreated with CX-4945 or TTP22, and, before lysis for the in vitro taspase 1 cleavage assay, cleavage efficiency was significantly diminished compared with the DMSO control by the recombinant taspasel protein (Fig. 5F,G). Moreover, an in vitro CKII phosphorylation assay was established demonstrating that the MLL wild-type peptide can be dose-dependently phosphorylated by recombinant CKII but not by the MLL-AA peptide (Fig. $5 \mathrm{H}$ ). The signal from MLL-AA was mostly attributed to autophosphorylation using no peptide as the negative control (Fig. 5H). Using our in vitro CKII phosphorylation assay platform, CX-4945 and TTP-22 both dose-dependently inhibited MLL wild-type peptide phosphorylation by CKII with $\mathrm{IC}_{50}$ values of 0.011 and $0.38 \mu \mathrm{M}$, respectively (Fig. 5I). Overall, our data revealed that CKII inhibition selectively increased the full-length MLL1 protein levels by decreasing the phosphorylation of MLL1 near its taspasel cleavage site.

CKII inhibition and increased stability and occupancy of full-length MLL1 on chromatin result in decreased $M L L$ chimera occupancy

Similar to taspase1 loss, CKII inhibitor treatment resulted in a global increase of MLL1 chromatin occupancy in 293T cells (Fig. 6A-D). When we treated SEM or MV4-11 leukemia cells (bearing MLL-AFF1/AF4 fusion) with CX-4945, 

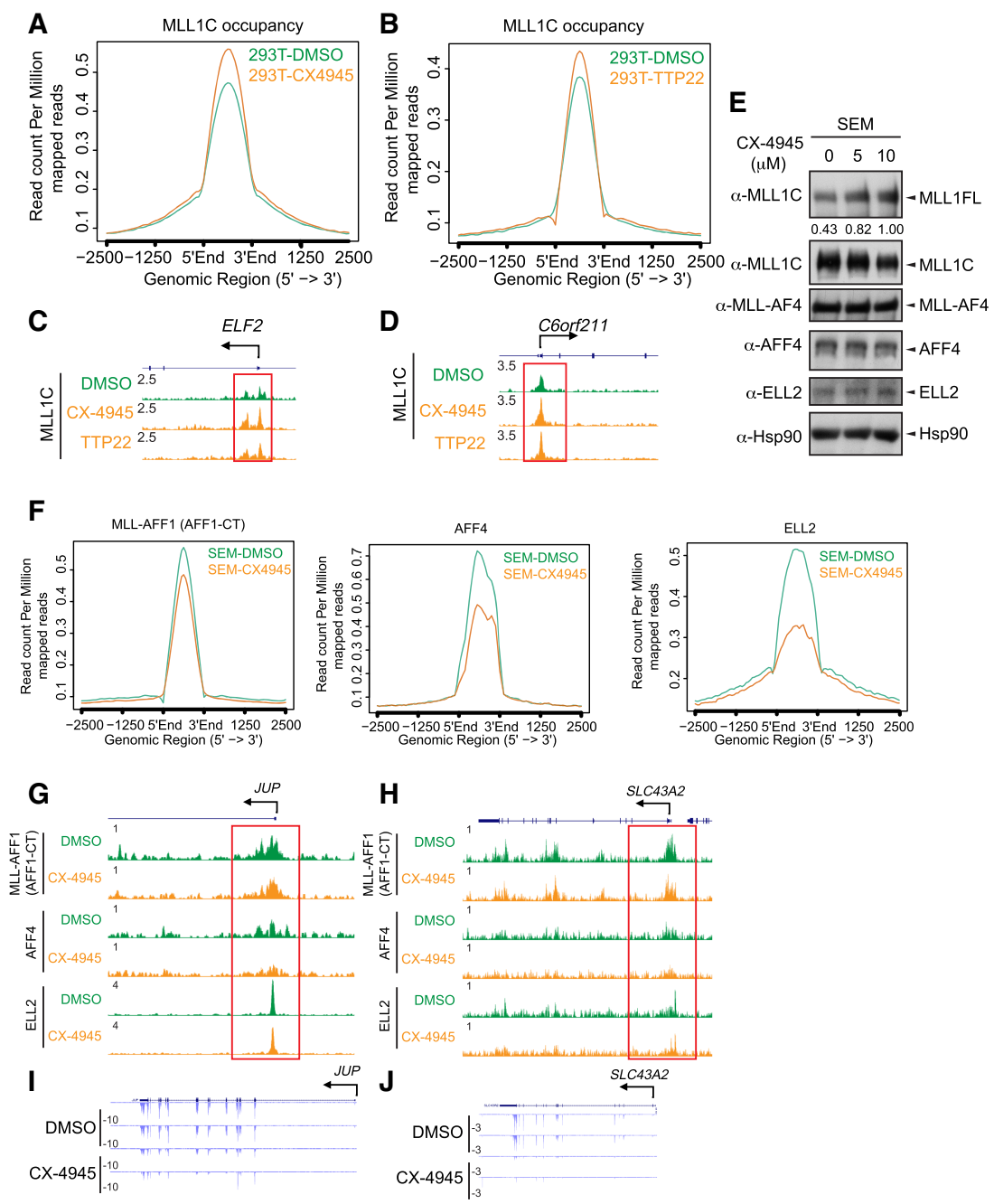

MLL1 full-length protein levels also increased without altering MLL-AF4 protein levels (Fig. 6E; Supplemental Fig. S7A). Depletion of CKII a or CKII $\alpha^{\prime}$ in these two cell lines also caused a consistent increase of MLL1 full-length protein levels (Supplemental Fig. S7B,C). CX-4945 treatment resulted in a dose-dependent growth inhibition of several MLL-rearranged leukemia cell lines, including SEM, MV4-11, and RS4;11 (Supplemental Fig. S7D). The genome-wide localization of MLL-AFF1, AFF4, and ELL2 was substantially decreased upon treatment with CX-4945 in SEM leukemic cells (Fig. 6F), suggesting that CKII inhibition led to displacement of the MLL chimeras from chromatin through competition from the stabilized wild-type MLL protein. The decrease of MLL1-AFF1, AFF4, and ELL2 binding at the promoter regions of JUP and $S L C 43 A 2$ genes (Fig. 6G,H) was also accompanied by decreased mRNA levels of these genes (Fig. 6I,J).

\section{CKII inhibitors can delay the progression of leukemia and improve survival in MLL-AF9 mouse models of leukemia}

To further examine the effect of CKII inhibition on leukemic progression through regulation of MLL processing
Figure 6. CKII inhibition increases genomewide MLL1 occupancy and displaces MLL chimeras from chromatin. $(A, B)$ MLL1C occupancy in CX-4945- or TTP22-treated cells is shown relative to DMSO control. A region within $2.5 \mathrm{~kb}$ around the center of MLL1C is displayed. $(C, D)$ Track examples of the MLL1 occupancy at the promoter regions of ELF2 and C6orf211. (E) SEM cells were treated with 0,5 , or $10 \mu \mathrm{M}$ CX-4945 for $30 \mathrm{~h}$, and Western blotting was performed to determine the MLL1 full-length, MLL1C, MLL-AF4 fusion, AFF4, and ELL2 protein levels. (F) MLL-AFF1, AFF4, and ELL2 occupancies were decreased by CX-4945 treatment in SEM cells. A region within $2.5 \mathrm{~kb}$ around the center of MLL-AFF1, AFF4, and ELL2 is displayed. $(G, H)$ CX-4945 treatment decreased MLL-AFF1 and SEC occupancy at the JUP and SLC43A2 genes in SEM cells. Genome browser views of MLL-AFF1 (AFF1-CT) and SEC component AFF4 and ELL2 occupancy at the JUP and SLC43A2 genes are shown. Red boxes indicate the promoterproximal regions with decreased MLL-AFF1, AFF4, and ELL2 occupancy. $(I, I)$ RNA-seq genome browser track examples indicate that JUP and SLC43A2 gene expression was decreased with CX-4945 treatment. in vivo, we studied the efficacy of CX-4945 in a MLLAF9 syngeneic mouse model. First, we treated irradiated C57BL/6 mice transplanted with MLL-AF9 leukemic cells with CX-4945 via oral gavage for $10 \mathrm{~d}$ and monitored the survival of these mice (Fig. 7A). CKII inhibition by CX-4945 significantly delayed leukemia progression and improved survival (Fig. 7B). Treating the CX-4945 compound via intraperitoneal injection (Fig. 7C) also significantly decreased the tumor burden as measured by IVIS (in vivo imaging system), delayed the progression of the disease, and extended the survival of the mice (Fig. 7D,E).

Together, our data suggest the following: (1) MLL1 cleavage by taspasel primes the protein for degradation. (2) In the absence of taspase1-dependent cleavage, the MLL1 protein is relatively stable and preferentially associates with chromatin. (3) CKII phosphorylation of MLL1 near the taspasel cleavage site facilitates the taspase1dependent cleavage event. (4) Stabilization of the fulllength MLL1 is achieved by pharmacological inhibition of CKII phosphorylation on MLL1. (5) The stabilized MLL1 protein excludes the MLL translocations from chromatin, suggesting a possible new therapeutic approach for the treatment of MLL-rearranged leukemia through the 
A

A MLL-AF9 syngeneic mouse model

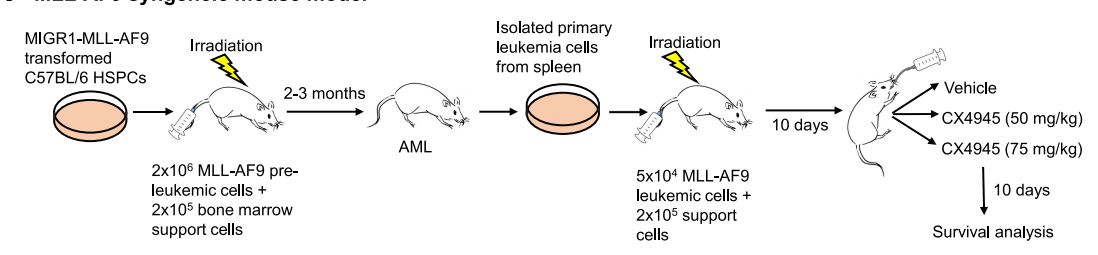

B

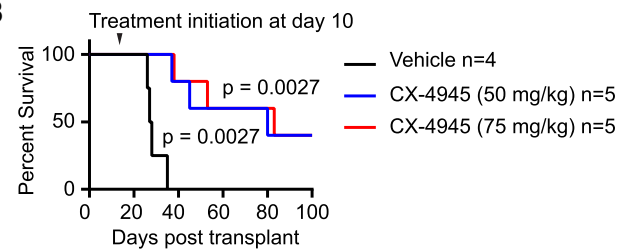

C

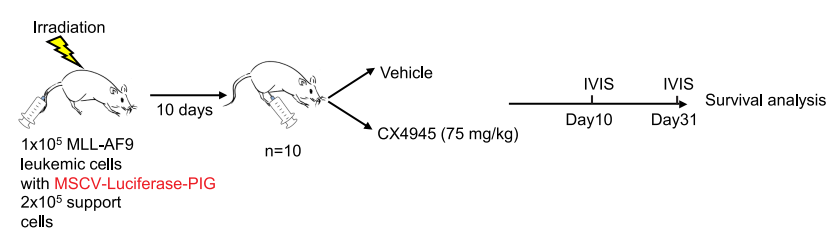

cells

D

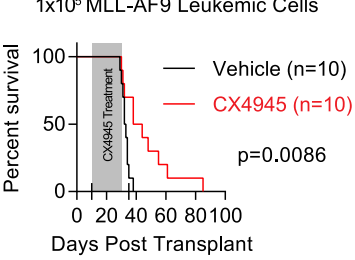

E

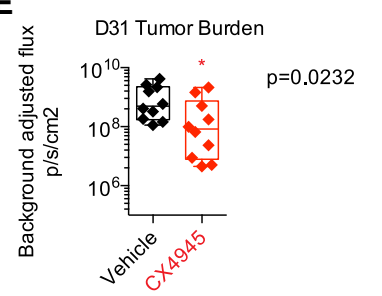

Figure 7. CKII inhibitors can delay the progression of leukemia and improve survival in a MLL-AF9 mouse model of MLL-rearranged leukemia. (A) Schematic of the development of secondary murine MLL-AF9 leukemia and CKII inhibitor treatment in a MLL-AF9 syngeneic mouse model. Drug treatments were started at day 10 after transplantation. (B) Kaplan-Meier survival curves of secondary transplanted C57BL/6 mice after vehicle and CX-4945 treatment at day 10. Vehicle or $50 \mathrm{mg} / \mathrm{kg}$ or $75 \mathrm{mg} / \mathrm{kg} \mathrm{CX-4945} \mathrm{was} \mathrm{adminis-}$ tered twice daily by oral gavage for a total of 20 treatments. Leukemia was confirmed at the end point for each transplanted mouse. The number $(n)$ indicates the number of mice in each group. The $P$-values were calculated using the log-rank test. (C) Schematic of the development of secondary murine MLL-AF9 leukemia and CKII inhibitor treatment via intraperitoneal injection in an MLL-AF9 syngeneic mouse model combined with IVIS. Drug treatments were started at day 10 after transplantation. (D) Kaplan-Meier survival curves of secondary transplanted C57BL/6 mice after vehicle and CX-4945 treatment at day 10 . Vehicle or $75 \mathrm{mg} / \mathrm{kg} \mathrm{CX-4945} \mathrm{was} \mathrm{administered}$ twice daily by intraperitoneal injection for a total of 20 treatments. The $P$-value was calculated using the log-rank test. (E) Tumor burden was measured by IVIS at day 31 after transplantation. The $P$-value was calculated using the Mann-Whitney test. regulation of MLL stability via regulation of its taspase1dependent cleavage.

\section{Discussion}

The regulation of MLL1 stability is a precise process that determines its occupancy at its target genes (Liang et al. 2017). In the present study, we demonstrated that the cleavage of MLL1 by taspase1 may cause a conformational alteration and expose MLL1 to certain E3 ligases or the MLL1 PHD2 itself to undergo the degradation process (Wang et al. 2012b; Liang et al. 2017). Other studies have demonstrated that the $\mathrm{N}$ terminus and $\mathrm{C}$ terminus of MLL1 undergo distinct degradation processes in which the MLL1 $\mathrm{N}$ terminus undergoes degradation in the nucleus, while the MLL1 C terminus is dependent on the proteasome-mediated degradation in the cytoplasm (Yokoyama et al. 2011). Our biochemical analyses demonstrated that the proteolytic cleavage of MLL1 by taspase1 is coupled with the degradation process, thus controlling the turnover of MLL1 protein on chromatin. Our study demonstrates that preventing the proteolytic processing subverts these degradation mechanisms. In the majority of cases, the $M L L$ leukemogenic rearrangements generate fusion proteins with an N-terminal portion of MLL1 fused in-frame to the C-terminal translocation partner, with the MLL break point $\mathrm{N}$-terminal to the taspasel cleavage site (Hess 2004). This renders the fusion proteins resistant to ubiquitin-proteasome-mediated degradation (Wang et al. 2012a; Liang et al. 2017), rendering the oncogenic chimeras extremely stable, with concomitant high occupancy on chromatin.

Proteolysis of nuclear proteins is a common mechanism essential for the proper activation of their downstream target genes and for regulating chromatin structure /von Mikecz 2006). Here, we found that the proteolysis of MLL1 is also required for the regulated release of MLL1 from the chromatin, adding a new layer of epigenetic regulation of the cross-talk between histone H3K4 methylation and the degradation apparatus of the methyltransferase. We found that taspase1-dependent cleavage of MLL1 facilitates its degradation to control the levels of MLL1, reminiscent of that of TFIIA (Høiby et al. 2004; Zhou et al. 2006), albeit with distinct ubiquitin-proteasome pathways. It remains to be identified which ubiquitin machineries function downstream from taspase 1 to control MLL1 turnover in the nucleus. Taspase1 localizes and functions in both the nucleus and the cytoplasm (Natarajan et al. 2010; Bier et al. 2011). Whether there are additional substrates or any ubiquitin-proteasome pathway proteins that are processed by taspase 1 is an important area of future investigation to fully understand the roles of taspase1 in normal development and disease settings. Taspase 1 knockout models represent valuable tools to investigate the functions of taspase 1 , the only protease in the type 2 asparaginase family. 
Loss of taspase 1 impedes cancer cell proliferation and tumor progression in breast cancer (Chen et al. 2010, 2012; Dong et al. 2014). Surprisingly, numerous membrane proteins are affected with the loss of taspase1, and this resulted in the altered extracellular matrix organization and regulation of cell adhesion (data not shown). This consequence of taspasel loss leads to the possibility that taspase 1 expression may be important for the tumor progression in the tumor microenvironment, where the membrane receptor proteins directly contact the immune cells to conduct the cross-talk. Therefore, it will be interesting to observe the effect of taspase1 knockout in the in vivo system and tumor progression.

Taspase1 represents a desired therapeutic target for a variety of cancers due to its overexpression in solid and liquid malignancies (Wünsch et al. 2016). However, due to its unique structure and function and potent enzymatic activity, it remains a challenging therapeutic target for leukemia and other solid tumors. Our identification of a pathway that regulates the substrate cleavage by taspase1 through CKII-dependent MLL1 phosphorylation opens additional therapeutic targets that are involved in this process (Figs. 5, 6). Thus, the stabilization of MLL1 through cleavage inhibition provides us with a paradigm in the development of therapies for MLL-rearranged leukemia and other cancers caused by translocations or taspasel overexpression.

\section{Materials and methods}

Cell culture

Cell lines were purchased from American Type Culture Collection. The 293T, MCF7, and HCT116 cell lines were maintained in Dulbecco's modified Eagle's medium (DMEM) (Gibco) supplemented with $10 \%$ fetal bovine serum (FBS) (Gibco) at $37^{\circ} \mathrm{C}$ with $5 \% \mathrm{CO}_{2}$. SEM was maintained in IMDM with $10 \%$ FBS. MV411 and RS4;11 were maintained in RPMI 1640 supplemented with 10\% FBS and nonessential amino acids. For the CHX chase experiment, indicated concentrations of CHX (Sigma) or MG132 (Sigma) were added to the culture medium at the indicated time points before harvesting the cells. For CKII inhibitor treatment, the indicated concentrations were added to the cell culture for $30 \mathrm{~h}$ before harvesting the cells for a Western blot or an in vitro taspase1 assay. CX-4945, TTP22, DMAT, and TTB were purchased from ApexBio.

Knockout of taspase 1 by CRISPR/Cas9 targeted genome editing

Cells were cotransfected with gRNA and pX330-U6-Chimeric_BB-CBh-hSpCas9 (Cong and Zhang 2015) and another vector with puromycin resistance using Lipofectamine 2000 (Thermo Fisher Scientific) and selected with puromycin (Thermo Fisher Scientific) at $2 \mu \mathrm{g} / \mathrm{mL}$ for $3 \mathrm{~d}$. Cells were seeded in 96-well plates and selected for single clones after 2-3 wk. Genomic DNA was isolated using genomic lysis buffer $(10 \mathrm{mM}$ Tris- $\mathrm{HCl}$ at $\mathrm{pH} 7.5$, $10 \mathrm{mM}$ EDTA, $10 \mathrm{mM} \mathrm{NaCl}, 0.5 \%$ sarcosyl) for $2 \mathrm{~h}$ at $60^{\circ} \mathrm{C}$ and precipitation buffer (150 mM NaCl in 100\% EtOH) for $30 \mathrm{~min}$ at room temperature. PCR screening was performed using the primers listed in Supplemental Table 1 and further confirmed by Western blot and RNA-seq. pX330-U6-Chimeric_BBCBh-hSpCas9 was a gift from Feng Zhang (Addgene, plasmid no. 42230).
Virus packaging, infection, and generation of stable cell lines

Lentiviruses for knocking down MLL1, taspase1, CKIIa, and CKII $\alpha^{\prime}$ were packaged as described previously (Zhao et al. 2015). The shRNA sequences used are listed in Supplemental Table 1. Cells were selected with $2 \mu \mathrm{g} / \mathrm{mL}$ puromycin for $3 \mathrm{~d}$ before Western blotting and ChIP-seq experiments.

\section{Immunofluorescence}

Immunofluorescence was performed as described previously (Wang et al. 2014, 2017). Anti-MLL1N (D2M7U) and MLL1C (D6G8N) antibodies were purchased from Cell Signaling Technology. Anti-MLL2C antibody was validated in our previous studies (Hu et al. 2013).

\section{Immunoprecipitation}

293 cells were lysed in Triton X-100 lysis buffer (50 mM Tris at pH 8.0, $150 \mathrm{mM} \mathrm{NaCl}, 0.5 \%$ Triton X-100, 10\% glycerol, $1 \mathrm{mM}$ DTT, protease inhibitors, benzonase). After centrifugation at $13,000 \mathrm{~g}$ for $10 \mathrm{~min}$, the supernatants (1 $\mathrm{mg}$ of total protein) were collected and incubated with anti-Flag M2 affinity gel for $2 \mathrm{~h}$ at $4^{\circ} \mathrm{C}$ with rotation. Samples were washed with lysis buffer four times and competed with $3 \times$ Flag peptide for $15 \mathrm{~min}$ with vigorous agitation. Proteins were resuspended in a $5 \times$ SDS sample loading buffer, heated for $5 \mathrm{~min}$ to $95^{\circ} \mathrm{C}$, and subjected to SDS-PAGE.

\section{Western blot analysis}

Western blot analysis was performed as described previously (Zhao et al. 2013). Anti-TFIIA and anti-RbBP5 antibodies were purchased from Bethyl Laboratories. Anti-taspasel was from Thermo Fisher Scientific. Anti-MLL2N and MLL2C antibodies and anti-histone $\mathrm{H} 3, \mathrm{H} 3 \mathrm{~K} 4 \mathrm{me} 1, \mathrm{H} 3 \mathrm{~K} 4 \mathrm{me} 2$, and $\mathrm{H} 3 \mathrm{~K} 4 \mathrm{me} 3$ antibodies were homemade and validated in our previous studies (Hu et al. 2013; Rickels et al. 2016). Anti-B-tubulin (E7) was purchased from the Developmental Studies Hybridoma Bank. Anti-Hsp90 antibodies were purchased from Santa Cruz Biotechnology. Menin (no. 6891), LEDGF (no. 2088), MLL1N (no. 14689), MLL1C (no. 14197), ASH2L (no. 5019), PARP (no. 9542), and p21 (no. 2947) antibodies were purchased from Cell Signaling Technology.

\section{Cell proliferation assay}

Cell proliferation was measured by cell counting using the ViCELL cell counter (Beckman Coulter Life Sciences). Culture medium was changed freshly every $2 \mathrm{~d}$.

\section{Two-dimensional colony formation assay}

Colony formation assay was performed as described previously (Noetzel et al. 2012). 293T cells were seeded at 200 cells per well in six-well plates, and culture medium was replaced every $4 \mathrm{~d}$ for 2 wk. Cells were then fixed with $3.7 \%$ paraformaldehyde and stained with $0.05 \%$ crystal violet.

\section{In vitro tasapse1 cleavage assay}

Approximately $25 \mu \mathrm{g}$ of taspase1 knockout whole-cell lysates was incubated with various amounts of His-taspase1 purified from BL21 Escherichia coli for $1 \mathrm{~h}$ at $30^{\circ} \mathrm{C}$ in the cleavage buffer (100 mM HEPES at $\mathrm{pH} 7.9,5 \mathrm{mM} \mathrm{MgCl}_{2}, 20 \mathrm{mM} \mathrm{KCl}, 10 \%$ sucrose, $5 \mathrm{mM}$ DTT). Cleavage efficiency was detected by 
Western blotting for MLL1C and TFIIA using Hsp90 as the loading control.

\section{In vitro CKII phosphorylation assay}

The in vitro phosphorylation was performed with ADP-Glo kinase assay (Promega). Briefly, $20 \mathrm{ng}$ of CKII was preincubated with various concentrations of CX-4945 or TTP-22 for $30 \mathrm{~min}$ at room temperature. The in vitro phosphorylation reaction took place at $30^{\circ} \mathrm{C}$ with $400 \mu \mathrm{M}$ peptides (MLL wild-type/ MLL-AA/no peptide) and $100 \mu$ M ATP in $1 \times$ reaction buffer. Recombinant CKII was purchased from New England Biolabs, and MLL wild-type or MLL-AA peptides were synthesized by Genscript.

Next-generation sequencing data processing

RNA-seq and ChIP-seq samples were sequenced with Illumina NextSeq technology, and output data were processed with bcl2fastq. Sequence quality was assessed using FastQC version 0.11 .2 (http://www.bioinformatics.babraham.ac.uk/projects/ fastqc), and quality trimming was done using Trimmomatic (Bolger et al. 2014). RNA-seq and ChIP-seq reads were aligned to the hg19 genome using TopHat version 2.0.9 (Kim et al. 2013) and Bowtie version 0.12.9 (Langmead et al. 2009), and only uniquely mapped reads with a two-mismatch threshold were considered for downstream analysis. Gene annotations from Ensembl 72 were used. Output bam files were converted into bigwig track files to display coverage throughout the genome (in reads per million [RPM]) using the GenomicRanges package (Lawrence et al. 2013) as well as other standard Bioconductor R packages.

\section{RNA-seq analysis}

Gene count tables were constructed using HTseq (Anders et al. 2015) with Ensembl gene annotations and used as input for edgeR 3.0.8 (Robinson et al. 2010). Genes with Benjamini-Hochburg adjusted $P$-values of $<0.01$ were considered to be differentially expressed.

\section{ChIP-seq analysis}

For each ChIP assay, $5 \times 10^{7}$ cells were used, and the assay was performed as described previously (Chen et al. 2015). Peaks were called with MACS version 1.4.2 (Zhang et al. 2008) using default parameters and annotated with HOMER (Heinz et al. 2010). Metaplots were generated using ngsplot (Shen et al. 2014). MLL1 or MLL2 peaks from wild-type and taspasel knockout as well as control and the respective knockdowns were merged. BEDtools was used to determine the raw counts at the merged peaks (Quinlan and Hall 2010). Using in-house Perl scripts, raw counts at each peak were converted to RPKM (reads per kilobase per million mapped reads) values with total library counts, and $\log _{2}$ fold change values between conditions were then computed with these normalized values. Differential occupancy of MLL1 was evaluated by edgeR, and peaks with Benjamini-Hochburg-adjusted $P$-values of $<0.05$ were considered to be differentially occupied. Nearest genes were identified using in-house Perl scripts based on distances between peak centers and transcription start sites.

\section{MLL-AF9 leukemia cell generation}

Hematopoietic stem/progenitor cell (HSPCs) from C57BL/6 mice were isolated as described above and spinoculated with MIGR1MLL-AF9-IRES-Neo retrovirus at $2500 \mathrm{rpm}$ for $90 \mathrm{~min}$ at $32^{\circ} \mathrm{C}$.
Two days following spinoculation, HSPCs were treated with G418 at a 1:125 concentration (Sigma). Once all nontransduced cells were eliminated, the remaining cells were transferred to leukemic cell medium consisting of RPMI-1640 supplemented with $10 \%$ FBS, penicillin/streptomycin, L-glutamine, $100 \mathrm{ng} / \mathrm{mL}$ recombinant $\mathrm{mSCF}, 50 \mathrm{ng} / \mathrm{mL}$ recombinant $\mathrm{mIL} 6$, and $20 \mathrm{ng} / \mathrm{mL}$ recombinant mIL3 to expand. We transplanted $2 \times 10^{6}$ MLL-AF9 preleukemic cells into irradiated recipient mice via the tail vein along with $2 \times 10^{5}$ bone marrow support cells. Mice developed disease after 2-3 mo, and spleens were harvested. Mononuclear cells from spleens of diseased mice were dissociated and cultured in leukemic cell medium with G418 for an additional $5 \mathrm{~d}$ to eliminate non-leukemic cells from culture. These cells were used for all MLL-AF9 leukemic cell studies.

\section{Leukemic cell transplantation and treatment}

Eight-week-old to 10-wk-old C57BL/6 female recipient mice were exposed to $9 \mathrm{~Gy}$ of ionizing radiation in a Gammacell 40 irradiator. Immediately prior to irradiation and $14 \mathrm{~d}$ afterward, mice were fed bactrim-supplemented water. Each mouse was injected with $5 \times 10^{4}$ MLL-AF9 leukemic cells as well as $2 \times 10^{5}$ wildtype bone marrow support cells by the tail vein following irradiation. After $10 \mathrm{~d}$ of recovery, mice were treated twice daily for 2 wk ( $5 \mathrm{~d}$ on, $2 \mathrm{~d}$ off, and $5 \mathrm{~d}$ on) with either vehicle or CX-4945 at the indicated doses by oral gavage or intraperitoneal injection. All mice were housed at Northwestern University, and all studies were performed with prior Institutional Animal Care and Use Committee approval. CX-4945 compound was purchased from APExBIO and synthesized in-house according to the previously published procedure (Pierre et al. 2011).

\section{Data availability}

Next-generation sequencing data sets have been deposited at Gene Expression Omnibus with accession number GSE90762.

\section{Acknowledgments}

We are grateful to Dr. Edwin Smith for critical reading of the manuscript. We are also grateful to Anna Whelan and Michaela Twarogova for technical assistance in preparation of recombinant taspase1. Z.Z. is supported in part by National Institutes of Health $(\mathrm{NIH}) /$ National Cancer Institute (NCI) training grant T32 CA070085 and Alex's Lemonade Stand Foundation (ALSF) Young Investigator Award by ALSF and Northwestern Mutual. L.W. is supported by the Training Program in Signal Transduction and Cancer (T32-CA070085). E.T.B. is supported by Research Specialist Award R50-CA221848 from the NCI. Studies in regard to the role of the MLL/COMPASS family of histone methyltransferases in leukemic pathogenesis are supported in part by the generous Outstanding Investigator Award (R35-CA197569) from the NCI to A.S.

Author contributions: Z.Z. and A.S. were the main contributors to the design implementation and writing of the manuscript and collaborated with colleagues in its full implementation.

\section{References}

Anders S, Pyl PT, Huber W. 2015. HTSeq-a Python framework to work with high-throughput sequencing data. Bioinformatics 31: 166-169. doi:10.1093/bioinformatics/btu638

Armstrong SA, Staunton JE, Silverman LB, Pieters R, den Boer ML, Minden MD, Sallan SE, Lander ES, Golub TR, Korsmeyer 
SJ. 2002. MLL translocations specify a distinct gene expression profile that distinguishes a unique leukemia. Nat Genet 30: 41-47. doi:10.1038/ng765

Ayton PM, Cleary ML. 2003. Transformation of myeloid progenitors by MLL oncoproteins is dependent on Hoxa7 and Hoxa9. Genes Dev 17: 2298-2307. doi:10.1101/gad.1111603

Bier C, Knauer SK, Docter D, Schneider G, Krämer OH, Stauber RH. 2011. The importin-a/nucleophosmin switch controls taspase1 protease function. Traffic 12: 703-714. doi:10.1111/ j.1600-0854.2011.01191.x

Blom N, Sicheritz-Pontén T, Gupta R, Gammeltoft S, Brunak S. 2004. Prediction of post-translational glycosylation and phosphorylation of proteins from the amino acid sequence. Proteomics 4: 1633-1649. doi:10.1002/pmic.200300771

Bolger AM, Lohse M, Usadel B. 2014. Trimmomatic: a flexible trimmer for Illumina sequence data. Bioinformatics 30: 2114-2120. doi:10.1093/bioinformatics/btu170

Capotosti F, Hsieh JJ, Herr W. 2007. Species selectivity of mixedlineage leukemia/trithorax and HCF proteolytic maturation pathways. Mol Cell Biol 27: 7063-7072. doi:10.1128/MCB. 00769-07

Capotosti F, Guernier S, Lammers F, Waridel P, Cai Y, Jin J, Conaway JW, Conaway RC, Herr W. 2011. O-GlcNAc transferase catalyzes site-specific proteolysis of HCF-1. Cell 144: 376388. doi:10.1016/j.cell.2010.12.030

Chen DY, Liu H, Takeda S, Tu HC, Sasagawa S, Van Tine BA, Lu D, Cheng EH, Hsieh JJ. 2010. Taspase1 functions as a nononcogene addiction protease that coordinates cancer cell proliferation and apoptosis. Cancer Res 70: 5358-5367. doi: 10.1158/0008-5472.CAN-10-0027

Chen DY, Lee Y, Van Tine BA, Searleman AC, Westergard TD, Liu H, Tu HC, Takeda S, Dong Y, Piwnica-Worms DR, et al. 2012. A pharmacologic inhibitor of the protease Taspase1 effectively inhibits breast and brain tumor growth. Cancer Res 72: 736-746. doi:10.1158/0008-5472.CAN-11-2584

Chen FX, Woodfin AR, Gardini A, Rickels RA, Marshall SA, Smith ER, Shiekhattar R, Shilatifard A. 2015. PAF1, a molecular regulator of promoter-proximal pausing by RNA polymerase II. Cell 162: 1003-1015. doi:10.1016/j.cell.2015. 07.042

Cong L, Zhang F. 2015. Genome engineering using CRISPR-Cas9 system. Methods Mol Biol 1239: 197-217. doi:10.1007/978-14939-1862-1_10

Daou S, Mashtalir N, Hammond-Martel I, Pak H, Yu H, Sui G, Vogel JL, Kristie TM, Affar el B. 2011. Crosstalk between OGlcNAcylation and proteolytic cleavage regulates the host cell factor-1 maturation pathway. Proc Natl Acad Sci 108: 2747-2752. doi:10.1073/pnas.1013822108

Dong Y, Van Tine BA, Oyama T, Wang PI, Cheng EH, Hsieh JJ. 2014. Taspase 1 cleaves MLL1 to activate cyclin E for HER2/ neu breast tumorigenesis. Cell Res 24: 1354-1366. doi: $10.1038 / \mathrm{cr} .2014 .129$

Fair K, Anderson M, Bulanova E, Mi H, Tropschug M, Diaz MO. 2001. Protein interactions of the MLL PHD fingers modulate MLL target gene regulation in human cells. Mol Cell Biol 21: 3589-3597. doi:10.1128/MCB.21.10.3589-3597.2001

Heinz S, Benner C, Spann N, Bertolino E, Lin YC, Laslo P, Cheng JX, Murre C, Singh H, Glass CK. 2010. Simple combinations of lineage-determining transcription factors prime cis-regulatory elements required for macrophage and $\mathrm{B}$ cell identities. Mol Cell 38: 576-589. doi:10.1016/j.molcel.2010.05.004

Hess JL. 2004. Mechanisms of transformation by MLL. Crit Rev Eukaryot Gene Expr 14: 235-254. doi:10.1615/CritRev EukaryotGeneExpr.v14.i4.10
Høiby T, Mitsiou DI, Zhou HQ, Erdjument-Bromage H, Tempst P, Stunnenberg HG. 2004. Cleavage and proteasome-mediated degradation of the basal transcription factor TFIIA. EMBO $J$ 23: 3083-3091. doi:10.1038/sj.emboj.7600304

Hornbeck PV, Zhang B, Murray B, Kornhauser JM, Latham V, Skrzypek E. 2015. PhosphoSitePlus, 2014: mutations, PTMs and recalibrations. Nucleic Acids Res 43: D512-D520. doi: 10.1093/nar/gku1267

Hsieh JJ, Cheng EH, Korsmeyer SJ. 2003a. Taspase1: a threonine aspartase required for cleavage of MLL and proper HOX gene expression. Cell 115: 293-303. doi:10.1016/S0092-8674(03) 00816-X

Hsieh JJ, Ernst P, Erdjument-Bromage H, Tempst P, Korsmeyer SJ. 2003b. Proteolytic cleavage of MLL generates a complex of Nand C-terminal fragments that confers protein stability and subnuclear localization. Mol Cell Biol 23: 186-194. doi: 10.1128/MCB.23.1.186-194.2003

Hu D, Garruss AS, Gao X, Morgan MA, Cook M, Smith ER, Shilatifard A. 2013. The Mll2 branch of the COMPASS family regulates bivalent promoters in mouse embryonic stem cells. Nat Struct Mol Biol 20: 1093-1097. doi:10.1038/nsmb.2653

Khan JA, Dunn BM, Tong L. 2005. Crystal structure of human Taspase1, a crucial protease regulating the function of MLL. Structure 13: 1443-1452. doi:10.1016/j.str.2005.07.006

Kim D, Pertea G, Trapnell C, Pimentel H, Kelley R, Salzberg SL. 2013. TopHat2: accurate alignment of transcriptomes in the presence of insertions, deletions and gene fusions. Genome Biol 14: R36. doi:10.1186/gb-2013-14-4-r36

Langmead B, Trapnell C, Pop M, Salzberg SL. 2009. Ultrafast and memory-efficient alignment of short DNA sequences to the human genome. Genome Biol 10: R25. doi:10.1186/gb-200910-3-r25

Lawrence M, Huber W, Pages H, Aboyoun P, Carlson M, Gentleman R, Morgan MT, Carey VJ. 2013. Software for computing and annotating genomic ranges. PLoS Comput Biol 9: e1003118. doi:10.1371/journal.pcbi.1003118

Liang K, Volk AG, Haug JS, Marshall SA, Woodfin AR, Bartom ET, Gilmore JM, Florens L, Washburn MP, Sullivan KD, et al. 2017. Therapeutic targeting of MLL degradation pathways in MLL-rearranged leukemia. Cell 168: 59-72.e13. doi: 10.1016/j.cell.2016.12.011

Lin C, Smith ER, Takahashi H, Lai KC, Martin-Brown S, Florens L, Washburn MP, Conaway JW, Conaway RC, Shilatifard A. 2010. AFF4, a component of the ELL/P-TEFb elongation complex and a shared subunit of MLL chimeras, can link transcription elongation to leukemia. Mol Cell 37: 429-437. doi:10.1016/j.molcel.2010.01.026

Luo Z, Lin C, Shilatifard A. 2012. The super elongation complex (SEC) family in transcriptional control. Nat Rev Mol Cell Biol 13: $543-547$. doi:10.1038/nrm3417

Meggio F, Marin O, Pinna LA. 1994. Substrate specificity of protein kinase CK2. Cell Mol Biol Res 40: 401-409.

Miller T, Krogan NJ, Dover J, Erdjument-Bromage H, Tempst P, Johnston M, Greenblatt JF, Shilatifard A. 2001. COMPASS: a complex of proteins associated with a trithorax-related SET domain protein. Proc Natl Acad Sci 98: 12902-12907. doi:10.1073/pnas.231473398

Milne TA, Briggs SD, Brock HW, Martin ME, Gibbs D, Allis CD, Hess JL. 2002. MLL targets SET domain methyltransferase activity to Hox gene promoters. Mol Cell 10: 1107-1117. doi:10.1016/S1097-2765(02)00741-4

Nakamura T, Mori T, Tada S, Krajewski W, Rozovskaia T, Wassell R, Dubois G, Mazo A, Croce CM, Canaani E. 2002. ALL-1 is a histone methyltransferase that assembles a 
supercomplex of proteins involved in transcriptional regulation. Mol Cell 10: 1119-1128. doi:10.1016/S1097-2765(02) 00740-2

Natarajan TG, Kallakury BV, Sheehan CE, Bartlett MB, Ganesan N, Preet A, Ross JS, Fitzgerald KT. 2010. Epigenetic regulator MLL2 shows altered expression in cancer cell lines and tumors from human breast and colon. Cancer Cell Int 10: 13. doi:10.1186/1475-2867-10-13

Noetzel E, Rose M, Bornemann J, Gajewski M, Knüchel R, Dahl E. 2012. Nuclear transport receptor karyopherin- $\alpha 2$ promotes malignant breast cancer phenotypes in vitro. Oncogene 31: 2101-2114. doi:10.1038/onc.2011.403

Pierre F, Chua PC, O'Brien SE, Siddiqui-Jain A, Bourbon P, Haddach M, Michaux J, Nagasawa J, Schwaebe MK, Stefan E, et al. 2011. Discovery and SAR of 5-(3-chlorophenylamino) benzo[c][2,6]naphthyridine-8-carboxylic acid (CX-4945), the first clinical stage inhibitor of protein kinase CK2 for the treatment of cancer. I Med Chem 54: 635-654. doi:10.1021/ jm101251q

Piunti A, Shilatifard A. 2016. Epigenetic balance of gene expression by Polycomb and COMPASS families. Science 352: aad9780. doi:10.1126/science.aad9780

Quinlan AR, Hall IM. 2010. BEDTools: a flexible suite of utilities for comparing genomic features. Bioinformatics 26: 841-842. doi:10.1093/bioinformatics/btq033

Rickels R, Hu D, Collings CK, Woodfin AR, Piunti A, Mohan M, Herz HM, Kvon E, Shilatifard A. 2016. An evolutionary conserved epigenetic mark of Polycomb response elements implemented by Trx/MLL/COMPASS. Mol Cell 63: 318-328. doi:10.1016/j.molcel.2016.06.018

Robinson MD, McCarthy DJ, Smyth GK. 2010. edgeR: a Bioconductor package for differential expression analysis of digital gene expression data. Bioinformatics 26: 139-140. doi: 10.1093/bioinformatics/btp616

Rush J, Moritz A, Lee KA, Guo A, Goss VL, Spek EJ, Zhang H, Zha XM, Polakiewicz RD, Comb MJ. 2005. Immunoaffinity profiling of tyrosine phosphorylation in cancer cells. Nat Biotechnol 23: 94-101. doi:10.1038/nbt1046

Sarno S, Vaglio P, Meggio F, Issinger OG, Pinna LA. 1996. Protein kinase CK2 mutants defective in substrate recognition. Purification and kinetic analysis. J Biol Chem 271: 10595-10601. doi:10.1074/jbc.271.18.10595

Schuettengruber B, Bourbon HM, Di Croce L, Cavalli G. 2017. Genome regulation by polycomb and trithorax: 70 years and counting. Cell 171: 34-57. doi:10.1016/j.cell.2017.08.002

Shen L, Shao N, Liu X, Nestler E. 2014. ngs.plot: quick mining and visualization of next-generation sequencing data by integrating genomic databases. BMC Genomics 15: 284. doi: 10.1186/1471-2164-15-284

Shilatifard A, Duan DR, Haque D, Florence C, Schubach WH, Conaway JW, Conaway RC. 1997. ELL2, a new member of an ELL family of RNA polymerase II elongation factors. Proc Natl Acad Sci 94: 3639-3643. doi:10.1073/pnas.94.8.3639

Smith E, Lin C, Shilatifard A. 2011. The super elongation complex (SEC) and MLL in development and disease. Genes Dev 25: 661-672. doi:10.1101/gad.2015411

Stauber RH, Bier C, Knauer SK. 2012. Targeting Taspase1 for cancer therapy-letter. Cancer Res 72: 2912. doi:10.1158/00085472.CAN-12-0150

Takeda S, Chen DY, Westergard TD, Fisher JK, Rubens JA, Sasagawa S, Kan JT, Korsmeyer SJ, Cheng EH, Hsieh JJ. 2006. Proteolysis of MLL family proteins is essential for taspase1orchestrated cell cycle progression. Genes Dev 20: 23972409. doi:10.1101/gad.1449406 von Mikecz A. 2006. The nuclear ubiquitin-proteasome system. J Cell Sci 119: 1977-1984. doi:10.1242/jcs.03008

Wang P, Lin C, Smith ER, Guo H, Sanderson BW, Wu M, Gogol M, Alexander T, Seidel C, Wiedemann LM, et al. 2009. Global analysis of H3K4 methylation defines MLL family member targets and points to a role for MLL1-mediated H3K4 methylation in the regulation of transcriptional initiation by RNA polymerase II. Mol Cell Biol 29: 6074-6085. doi:10.1128/ MCB.00924-09

Wang J, Muntean AG, Hess JL. 2012a. ECSASB2 mediates MLL degradation during hematopoietic differentiation. Blood 119: 1151-1161. doi:10.1182/blood-2011-06-362079

Wang J, Muntean AG, Wu L, Hess JL. 2012b. A subset of mixed lineage leukemia proteins has plant homeodomain (PHD)-mediated E3 ligase activity. I Biol Chem 287: 43410-43416. doi:10.1074/jbc.M112.423855

Wang L, Zhao Z, Meyer MB, Saha S, Yu M, Guo A, Wisinski KB, Huang W, Cai W, Pike JW, et al. 2014. CARM1 methylates chromatin remodeling factor BAF155 to enhance tumor progression and metastasis. Cancer Cell 25: 21-36. doi:10.1016/ j.ccr.2013.12.007

Wang Q, Trevino LS, Wong RL, Medvedovic M, Chen J, Ho SM, Shen J, Foulds CE, Coarfa C, O'Malley BW, et al. 2016. Reprogramming of the epigenome by MLL1 links early-life environmental exposures to prostate cancer risk. Mol Endocrinol 30: 856-871. doi:10.1210/me.2015-1310

Wang L, Collings CK, Zhao Z, Cozzolino KA, Ma Q, Liang K, Marshall SA, Sze CC, Hashizume R, Savas JN, et al. 2017. A cytoplasmic COMPASS is necessary for cell survival and triplenegative breast cancer pathogenesis by regulating metabolism. Genes Dev 31: 2056-2066. doi:10.1101/gad.306092.117

Wong P, Iwasaki M, Somervaille TC, So CW, Cleary ML. 2007. Meis 1 is an essential and rate-limiting regulator of MLL leukemia stem cell potential. Genes Dev 21: 2762-2774. doi: 10.1101/gad.1602107

Wünsch D, Fetz V, Heider D, Tenzer S, Bier C, Kunst L, Knauer S, Stauber R. 2012. Chemico-genetic strategies to inhibit the leukemic potential of threonine aspartase-1. Blood Cancer I 2: e77. doi:10.1038/bcj.2012.22

Wunsch D, Hahlbrock A, Heiselmayer C, Backer S, Heun P, Goesswein D, Stocker W, Schirmeister T, Schneider G, Kramer OH, et al. 2015. Fly versus man: evolutionary impairment of nucleolar targeting affects the degradome of Drosophila's Taspase1. FASEB I 29: 1973-1985. doi:10.1096/fj.14262451

Wünsch D, Hahlbrock A, Jung S, Schirmeister T, van den Boom J, Schilling O, Knauer SK, Stauber RH. 2016. Taspase1: a 'misunderstood' protease with translational cancer relevance. Oncogene 35: 3351-3364. doi:10.1038/onc.2015.436

Yokoyama A, Kitabayashi I, Ayton PM, Cleary ML, Ohki M. 2002. Leukemia proto-oncoprotein MLL is proteolytically processed into 2 fragments with opposite transcriptional properties. Blood 100: 3710-3718. doi:10.1182/blood-2002-04-1015

Yokoyama A, Ficara F, Murphy MJ, Meisel C, Naresh A, Kitabayashi I, Cleary ML. 2011. Proteolytically cleaved MLL subunits are susceptible to distinct degradation pathways. J Cell Sci 124: 2208-2219. doi:10.1242/jcs.080523

Yokoyama A, Ficara F, Murphy MJ, Meisel C, Hatanaka C, Kitabayashi I, Cleary ML. 2013. MLL becomes functional through intra-molecular interaction not by proteolytic processing. PLoS One 8: e73649. doi:10.1371/journal.pone.0073649

Zeleznik-Le NJ, Harden AM, Rowley JD. 1994. 11q23 translocations split the 'AT-hook' cruciform DNA-binding region and the transcriptional repression domain from the activation domain of the mixed-lineage leukemia (MLL) gene. Proc 
Zhao et al.

Nat1 Acad Sci 91: 10610-10614. doi:10.1073/pnas.91.22. 10610

Zhang Y, Liu T, Meyer CA, Eeckhoute J, Johnson DS, Bernstein BE, Nusbaum C, Myers RM, Brown M, Li W, et al. 2008. Model-based analysis of ChIP-seq (MACS). Genome Biol 9: R137. doi:10.1186/gb-2008-9-9-r137

Zhang P, Bergamin E, Couture JF. 2013. The many facets of MLL1 regulation. Biopolymers 99: 136-145. doi:10.1002/bip.22126

Zhao Z, Wang L, Wen Z, Ayaz-Guner S, Wang Y, Ahlquist P, Xu W. 2013. Systematic analyses of the cytotoxic effects of com- pound $11 \mathrm{a}$, a putative synthetic agonist of photoreceptor-specific nuclear receptor (PNR), in cancer cell lines. PLoS One 8: e75198. doi:10.1371/journal.pone.0075198

Zhao Z, Wang L, Xu W. 2015. IL-13Ra2 mediates PNR-induced migration and metastasis in ERa-negative breast cancer. Oncogene 34: 1596-1607. doi:10.1038/onc.2014.53

Zhou HQ, Spicuglia S, Hsieh JJD, Mitsiou DJ, Hoiby T, Veenstra GJC, Korsmeyer SI, Stunnenberg HG. 2006. Uncleaved TFIIA is a substrate for taspase 1 and active in transcription. Mol Cell Biol 26: 2728-2735. doi:10.1128/MCB.26.7.2728-2735.2006 


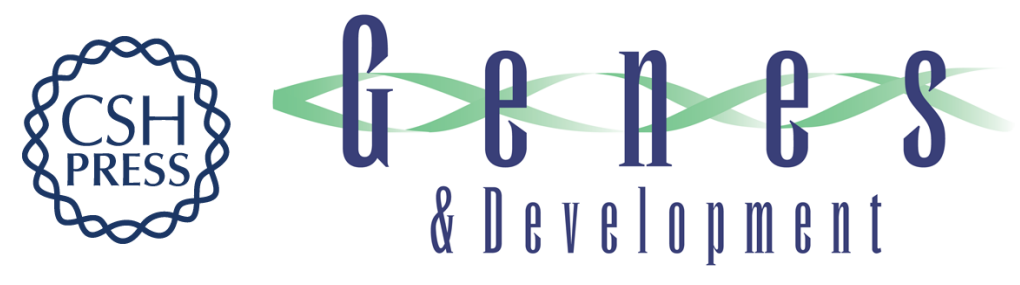

\title{
Regulation of MLL/COMPASS stability through its proteolytic cleavage by taspase1 as a possible approach for clinical therapy of leukemia
}

\author{
Zibo Zhao, Lu Wang, Andrew G. Volk, et al.
}

Genes Dev. 2019, 33: originally published online December 20, 2018

Access the most recent version at doi:10.1101/gad.319830.118

\section{Supplemental http://genesdev.cshlp.org/content/suppl/2018/12/20/gad.319830.118.DC1 Material}

References This article cites 68 articles, 24 of which can be accessed free at: http://genesdev.cshlp.org/content/33/1-2/61.full.html\#ref-list-1

Creative This article is distributed exclusively by Cold Spring Harbor Laboratory Press for the first Commons six months after the full-issue publication date (see

License http://genesdev.cshlp.org/site/misc/terms.xhtml). After six months, it is available under a Creative Commons License (Attribution-NonCommercial 4.0 International), as described at http://creativecommons.org/licenses/by-nc/4.0/.

Email Alerting Receive free email alerts when new articles cite this article - sign up in the box at the top Service right corner of the article or click here.

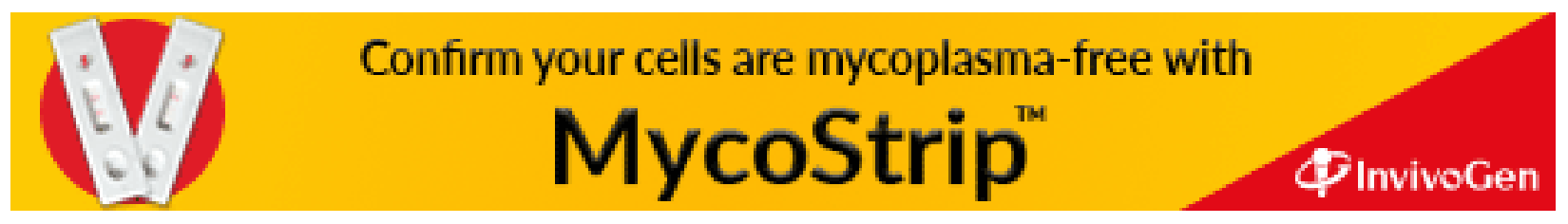

